\title{
Immuno-Metabolism and Microenvironment in Cancer: Key Players for Immunotherapy
}

\author{
Gaia Giannone , Eleonora Ghisoni *, Sofia Genta , Giulia Scotto , Valentina Tuninetti , \\ Margherita Turinetto and Giorgio Valabrega (1)
}

Candiolo Cancer Institute, FPO_IRCCS, University of Turin, 10060 Torino, Italy; gaia.giannone@ircc.it (G.G.); gentasofia@gmail.com (S.G.); giulia.scotto@ircc.it (G.S.); valentina.tuninetti@ircc.it (V.T.); margherita.turinetto@ircc.it (M.T.); giorgio.valabrega@ircc.it (G.V.)

* Correspondence: eleonora.ghisoni@ircc.it

Received: 25 May 2020; Accepted: 19 June 2020; Published: 21 June 2020

\begin{abstract}
Immune checkpoint inhibitors (ICIs) have changed therapeutic algorithms in several malignancies, although intrinsic and secondary resistance is still an issue. In this context, the dysregulation of immuno-metabolism plays a leading role both in the tumor microenvironment (TME) and at the host level. In this review, we summarize the most important immune-metabolic factors and how they could be exploited therapeutically. At the cellular level, an increased concentration of extracellular adenosine as well as the depletion of tryptophan and uncontrolled activation of the PI3K/AKT pathway induces an immune-tolerant TME, reducing the response to ICIs. Moreover, aberrant angiogenesis induces a hypoxic environment by recruiting VEGF, $\mathrm{T}_{\text {reg }}$ cells and immune-suppressive tumor associated macrophages (TAMs). On the other hand, factors such as gender and body mass index seem to affect the response to ICIs, while the microbiome composition (and its alterations) modulates both the response and the development of immune-related adverse events. Exploiting these complex mechanisms is the next goal in immunotherapy. The most successful strategy to date has been the combination of antiangiogenic drugs and ICIs, which prolonged the survival of patients with non-small-cell lung cancer (NSCLC) and hepatocellular carcinoma (HCC), while results from tryptophan pathway inhibition studies are inconclusive. New exciting strategies include targeting the adenosine pathway, TAMs and the microbiota with fecal microbiome transplantation.
\end{abstract}

Keywords: immunotherapy; metabolism; ICI resistance; macrophages; antiangiogenic; adenosine pathway; IDO inhibitors; PI3K/ALK pathway; microbiome

\section{Introduction}

The use of immune checkpoint inhibitors (ICIs) - monoclonal antibodies targeting programmed death protein 1 (PD-1), programmed death protein 1 ligand (PD-L1) and CTLA-4-has yielded impressive results in many settings and is currently a cornerstone in the treatment of metastatic melanoma, non-small-cell lung carcinoma (NSCLC), renal cell carcinoma (RCC), urothelial carcinoma and Hodgkin's lymphoma (HL) [1-5]. However, the clinical benefit is not uniform in all cancer types, ranging between an overall response rate (ORR) of $60-80 \%$ in relapsed/refractory Hodgkin lymphoma (HL) to less than $20 \%$ in ovarian cancer, prostate cancer and hormone positive breast cancer (BC), being the prospects for employing ICIs across a broader spectrum of tumors elusive so far [6,7]. Furthermore, clinical follow-up results have shown that a significant percentage of patients who are, at first, responders eventually relapse with drug-resistant disease [8-10].

The mechanisms occurring in primary and secondary resistant tumors are complex and involve both the tumor and the host itself (Figure 1) [10]. Among them, metabolic alterations that modify the 
tumor microenvironment (TME) and the physiological processes of the host play a central role in the development of resistance to ICIs [10-14].

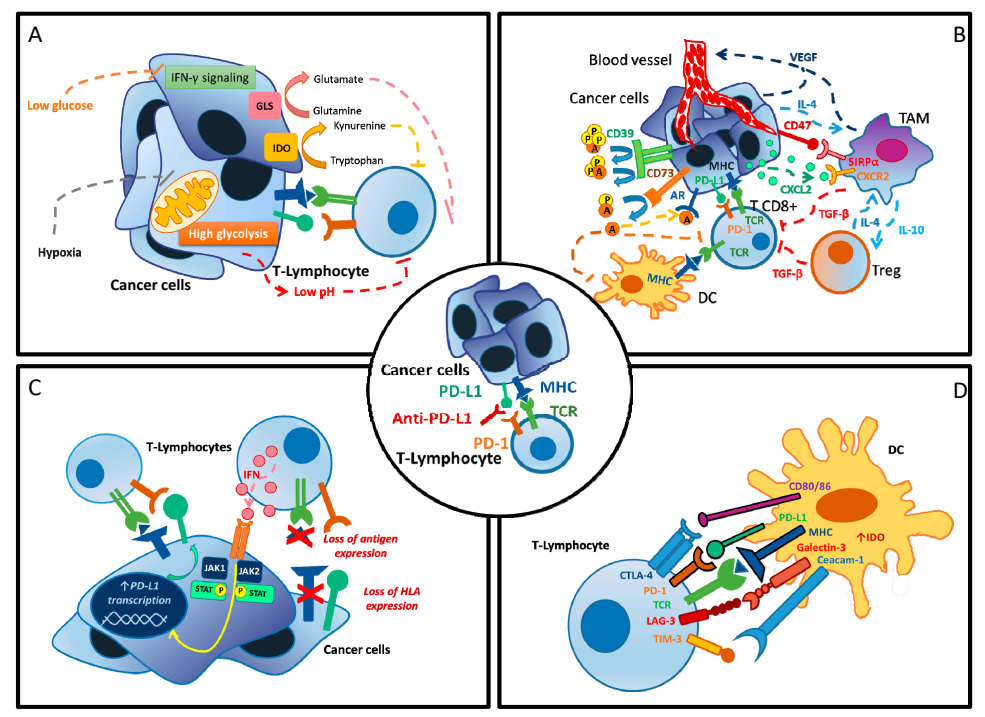

Figure 1. Mechanisms of resistance to PD-1/PD-L1 inhibition. (A) Metabolic dysregulation at cellular level. (B) Altered tumor microenvironment. (C) Tumor cell adaptation. (D) Activation of alternative immune checkpoint. $\mathrm{A}=$ adenosine, $\mathrm{AR}=$ androgen receptor, CTLA-4 = cytotoxic T-lymphocyte antigen 4, CXCL2 = C-X-C Motif Chemokine Ligand 2, CXCR2 = C-X-C Motif Chemokine Receptor 2, CD39 = ecto-nucleoside triphosphate diphosphohydrolase 1, CD47 = integrin-associated protein, CD80/86 = B7 protein, DC = dendritic cell, GLS = glutaminase, HLA = human leucocyte antigen, IL-4 = interleukin 4, IL-10 = interleukin 10, IDO = indoleamine 2,3-dioxygenase, IFN- $\gamma=$ interferon gamma, JAK1 = Janus kinase 1, JAK2 = Janus kinase 2, LAG-3 = lymphocyte-activation gene 3, $\mathrm{MHC}=$ major histocompatibility complex, $\mathrm{P}=$ phosphate, $\mathrm{PD}-1=$ protein cell death $1, \mathrm{PD}-\mathrm{L} 1=$ protein cell-death ligand 1, STAT- $3=$ signal transducer and activator of transcription $3, \operatorname{SIRP} \alpha=$ signal regulatory Protein alpha, TAM = tumor associated macrophages, TCR $=$ T-cell receptor, TGF- $\beta=$ transforming growth factor beta, Treg = regulatory T cells, VEGF = vascular endothelial growth factor.

In this review, we describe key tumor and host metabolic pathways involved in resistance to ICIs. Moreover, we focus on possible strategies to overcome primary and acquired resistance and to improve the response to ICIs.

We used the mesh keywords "immune-resistance", "metabolism", "immune checkpoints inhibitors" and "cancer", manually selecting the most relevant papers in this field. We thus performed research on clinicaltrial.gov, selecting key ongoing clinical trials targeting immune metabolism

\section{Resistance to ICIs: Immune Metabolism Dysregulation at Cellular Level}

Multiple mechanisms such as the overexpression of immune checkpoint molecules, loss of nutrients through vasculature impairment and dysregulation of metabolic pathways were recently shown to affect $\mathrm{T}$ cell recruitment and metabolic activities in the TME [15-18]. These alterations, indeed, can put immune cells into a hypo-responsive state, resulting in T cell exhaustion and anergy, impairing the immune control of tumor growth and the response to ICIs [19-21]. Moreover, a great deal of attention has recently been given to the role of macrophages and myeloid-derived suppressor cells (MDSC) as mediators of tumor-associated immune suppression and ICI-resistance [22,23].

\subsection{Inhibitors of the Adenosine Pathway}

Adenosine, generated from adenosine-tri-phosphate (ATP) by the ectonucleotidases CD39+ and $\mathrm{CD}^{+} 3^{+}$, is a well-described anti-inflammatory modulator of the immune response in peripheral 
tissues [24]. In inflamed and damaged tissues (i.e., cancers), extracellular adenosine can increase in concentration by up to 100 times and accumulate, inhibiting the effector functions of various immune cell populations-including $\mathrm{CD}^{+} \mathrm{T}$ cells, natural killer (NK) cells, dendritic cells (DC) and macrophages-but also enhance the proliferation and polarization of immunosuppressive cells, thereby promoting the progression of neoplasms [25].

There are four $G$ protein-coupled adenosine receptors (ARs): A1R, A2AR, A2BR and A3R [26]. Once activated, ARs induce the differentiation of monocytes to macrophages. Moreover, they stimulate the immune tolerance by promoting activity of macrophages and affecting their production of IL-12 and TNF $\alpha[27,28]$. Adenosine also influences neutrophils' activity: it reduces their adherence, transmigration and degranulation, finally causing an inhibition of Fc receptor-mediated phagocytosis and superoxide production [29-31].

Moreover, it has been demonstrated that $\mathrm{CD} 73^{+}$tumor cells are resistant to PD-1 blockade and that the simultaneous blockade of $\mathrm{CD}^{+} 3^{+}$and $\mathrm{PD}-1^{+}$could augment intra-tumoral $\mathrm{CD} 8^{+}$infiltration and enhance tumor control and survival in mice [32,33].

Several drugs such as those targeting $\mathrm{CD}_{3} 9^{+}$and $\mathrm{CD}_{3} 3^{+}$(that generate adenosine) and anti-AR agents (that consume adenosine) have been proven efficacious in preclinical studies and mouse tumor models [34].

Of note, the concurrent inhibition of CD39 and CD73 failed to potentiate the suppression of adenosine production in cancer cell lines [35].

Novel antibodies and small molecules targeting this pathway are now under investigation in early-phase clinical trials enrolling patients with advanced cancer and may be combined with standard chemotherapy and checkpoint inhibitors to revert immune resistance [36,37] (Table 1).

Table 1. Selected ongoing clinical trials exploring adenosine pathway.

\begin{tabular}{clcccc}
\hline $\begin{array}{c}\text { Molecular } \\
\text { Target }\end{array}$ & \multicolumn{1}{c}{ Agents } & Phase & Indications & $\begin{array}{c}\text { Clinical Trial } \\
\text { Identifier }\end{array}$ & Status \\
\hline CD73 & $\begin{array}{l}\text { Oleclumab }+ \\
\text { Durvalumab }\end{array}$ & II & $\begin{array}{c}\text { Renal, pancreatic, head } \\
\text { and neck and NSCLC with } \\
\text { DNA Methylation }\end{array}$ & NCT04262375 & $\begin{array}{c}\text { Active not } \\
\text { recruiting }\end{array}$ \\
\hline CD73 & $\begin{array}{l}\text { Oleclumab +/- } \\
\text { Durvalumab }\end{array}$ & I & Bladder cancer & NCT03773666 & Recruiting \\
\hline CD73 & $\begin{array}{l}\text { Carbo-taxol + } \\
\text { Durvalumab +/- } \\
\text { Oleclumab }\end{array}$ & I/II & $\begin{array}{c}\text { Triple negative breast } \\
\text { cancer (TNBC) }\end{array}$ & NCT03616886 & Recruiting \\
\hline CD73 & $\begin{array}{l}\text { Oleclumab + } \\
\text { Durvalumab vs. } \\
\text { Durvalumab }+ \\
\text { Monalizumab }\end{array}$ & II & NSCLC & NCT03822351 & Recruiting \\
\hline CD39 & $\begin{array}{l}\text { TTX-030 + } \\
\text { Pebrolizumab or } \\
\text { Chemotherapy }\end{array}$ & I & Solid tumors & NCT03884556 & Recruiting \\
\hline $\begin{array}{c}\text { CD73 } \\
\text { Anti-A2AR }\end{array}$ & $\begin{array}{l}\text { Oleclumab }+ \\
\text { AZD4635 }+ \\
\text { Osimertinib }\end{array}$ & I/II & NSCLC & NCT03381274 & Recruiting \\
\hline $\begin{array}{c}\text { CD73 } \\
\text { Anti-A2AR }\end{array}$ & $\begin{array}{l}\text { Oleclumab }+ \\
\text { AZD4635 }+ \\
\text { Durvalumab }\end{array}$ & II & Prostate cancer & NCT04089553 & Recruiting \\
\hline $\begin{array}{l}\text { CD39 } \\
\text { CD73 }\end{array}$ & $\begin{array}{l}\text { Oleclumab +/- } \\
\text { Durvalumab }\end{array}$ & I & Solid tumors & NCT04261075 & Recruiting \\
\hline
\end{tabular}

Recently, results from a Phase 1 trial exploring the combination of oleclumab (anti-CD73) and durvalumab were reported by Overman et al. [38]. Combination therapy showed encouraging clinical activity in pancreatic cancer (pancr) and, potentially, in colorectal cancer (CRC). Partial Response (PR) was observed for 1/21 CRC and 2/20 pancr patients; stable disease (SD) was observed in 2/21 $\mathrm{CRC}$ and 3/20 pancr patients, respectively. The most frequent toxicities in the expansion cohort were 
diarrhea (8.7\%), pyrexia (8.7\%), fatigue (6.5\%), and alanine aminotransferase (ALT) $(6.5 \%)$, aspartate aminotransferase (AST) (6.5\%), and ALP increases (6.5\%) [38].

\subsection{Inhibitors of Angiogenesis Pathways}

The TME is a complex system composed of both blood and lymphatic vessels and filled by immune cells (resident DCs, MDSCs, tumor-associated macrophages (TAMs) and resident and infiltrating T cells, including regulatory $\mathrm{T}$ cells $\left(\mathrm{T}_{\text {reg }}\right)$ ) but also stromal cells and CAFs (cancer activated fibroblasts) $[39,40]$. The cancer vasculature is aberrant both structurally and functionally and thus favors an hypoxic environment with a low $\mathrm{pH}$ and high interstitial pressure due to alternative lymphatic drainage, which in turn cause an immune-tolerant setting $[39,40]$. In this context, $\mathrm{T}_{\text {reg }}$ cells, TAMs and altered endothelial cells (ECs) replicate, while there is a reduction in DC maturation. All these changes induce altered antigen presentation and inhibit the migration of $\mathrm{CD} 8^{+} \mathrm{T}$ cells into the tumor core [41-43]. Furthermore, the abnormal TME lead TAMs to polarize from an anticancer M1-like phenotype towards an immunosuppressive M2 phenotype

Importantly, there is an upregulation of the PD-1/PD-L1 pathway both in immune cells and tumor cells, thus exhausting this mechanism. Lastly, from a biohumoral point of view, the vascular endothelial growth factor (VEGF) both induces the growth of MDSCs and enhances their immune-modulatory activity $[44,45]$.

Thus, drugs that modify the TME might improve the effectiveness of immunotherapy.

Antiangiogenic agents can alleviate immunosuppression, enabling CD8 ${ }^{+} \mathrm{T}$ cells to access the tumor tissue by relieving endothelial anergy and increasing adhesion molecule expression, thus augmenting checkpoint blockade activity [46,47].

Several clinical trials evaluating the combination of anti-PD-L1, anti-PD-1 or anti-CTLA-4 agents with anti-VEGF therapies (above all, bevacizumab) have been conducted in multiple tumor types and in different settings.

Given the number of these studies, we report key trials with available results (Table 2).

Of note, the anti-PD-L1 agent atezolizumab plus bevacizumab in combination with carboplatin and paclitaxel has already received FDA approval for the treatment of metastatic non-squamous NSCLC with no epidermal growth factor receptor (EGFR) or anaplastic lymphoma kinase (ALK) genomic tumor aberration based on the IMpower 150 results $[48,49]$. Regulatory approval is also under evaluation for the treatment of patients with unresectable hepatocellular carcinoma (HCC) not receiving prior systemic therapy, according to the IMbrave 150 study [50,51].

Table 2. Selected published clinical trials of immune checkpoint inhibitors (ICIs) in combination with bevacizumab.

\begin{tabular}{ccccc}
\hline $\begin{array}{c}\text { ICI Agent in } \\
\text { Combination with } \\
\text { Bevacizumab }\end{array}$ & Tumor Type & Phase & $\begin{array}{c}\text { Clinical Trial } \\
\text { Identifier }\end{array}$ & Reference \\
\hline Atezolizumab & NSCLC & III & $\begin{array}{c}\text { NCT02366143 } \\
\text { (IMpower 150) }\end{array}$ & Socinski et al., Lancet Resp, 2019 [49] \\
\hline Pembrolizumab & NSCLC & II & $\begin{array}{c}\text { NCT02039674 } \\
\text { (Keynote-021) }\end{array}$ & $\begin{array}{l}\text { Gandhi et al., Lancet Oncol, 2016 [52] } \\
\text { Gandhi et al., J Thor Oncol, 2019 [5] }\end{array}$ \\
\hline Atezolizumab & Hepato-cellular carcinoma (HCC) & III & $\begin{array}{c}\text { NCT03434379 } \\
\text { (IMbrave 150) }\end{array}$ & $\begin{array}{l}\text { Cheng et al., ESMO, 2019 [50] } \\
\text { Finn et al., NEJM, 2020 [51] }\end{array}$ \\
\hline Atezolizumab & Renal cell carcinoma (RCC) & III & $\begin{array}{c}\text { NCT02420821 } \\
\text { (IMmotion 151) }\end{array}$ & Motzer et al., Lancet, 2019 [53] \\
\hline Atezolizumab & RCC & II & $\begin{array}{c}\text { NCT01984242 } \\
\text { (IMmotion150) }\end{array}$ & Powles et al., Nat Med, 2018 [54] \\
\hline Atezolizumab & Microsattelite-instable (MSI) mCRC & Ib & NCT01633970 & Hochster et al., JCO, 2017 [55] \\
\hline Ipilimumab & Melanoma & I & NCT00790010 & Hodi et al., CancerImm, 2014 [56] \\
\hline
\end{tabular}


Additional trials evaluating anti-PD-L1 agents plus bevacizumab alone or as part of a larger regimen are actually recruiting in multiple cancer settings including CRC (NCT03869190 and NCT04068610), ovarian cancer (NCT03353831, NCT03806049, NCT03737643 and NCT03596281), HCC (NCT03847428 and NCT03778957) and BC (NCT03395899) and in patients with untreated melanoma brain metastases (NCT03175432) or mucosal melanoma (NCT04091217).

\subsection{Inhibitors of the Tryptophan-Kynurenine-Aryl Hydrocarbon Receptor Pathway}

Tryptophan catabolism is involved in physiological immune suppression through the tryptophankynurenine-aryl hydrocarbon receptor (Trp-Kyn-AhR) pathway, and it plays a role in acquired and intrinsic resistance to immunotherapy [57]. Three enzymes are involved in this pathway, among which indoleamine 2,3-dioxygenase (also called as IDO1) is the most studied, while another two enzymes-tryptophan-2,3-Dioxygenase (TDO), regulated by tryptophan, cholesterols, and prostaglandin $\mathrm{E} 2$, and IDO2, whose activity and regulation is uncertain-play a minor role in this pathway [58].

IDO1 is ubiquitously expressed, being mostly represented in the gut, lung and genital tracts [59]. It is expressed by macrophages and DCs, and its transcription is regulated, above all, by IFN $\gamma$ [59].

IDO1's immunosuppressive activities are both direct, through the depletion of tryptophan, and indirect, with the production of metabolites like kynurenine [60]. Indeed, the depletion of this essential amino acid leads to an accumulation of empty tryptophan-tRNA, with a stress response that causes $\mathrm{T}$ cell anergy, while kynureninecan inhibits the activation of T cells, inducing IDO1 expression in DC and the activation of $\mathrm{T}_{\text {reg }}$ lymphocytes [60,61].

The physiological role of IDO1 is to induce acquired immune tolerance (i.e., towards fetal antigens during pregnancy), while this enzyme seems not to be involved in the constitutive maintenance of immune tolerance toward self-antigens [62,63].

IDO1 also plays an aberrant role in tumors. Its presence has been observed in several cancer cell lines (endometrial, CRC and melanoma), and it shows a strong correlation with a worse outcome, lower presence of tumor infiltrating lymphocytes (TILs) and high percentage of $\mathrm{T}_{\text {reg }}$ cells [64-66].

Moreover, IDO1 expression in the peritumoral stroma strongly correlates with a low immune response. High IDO1 in sentinel lymph nodes has demonstrated to be associated with a reduction in TILs and worse prognosis in melanoma patients [67]. It exerts an inhibitory role and reduces the response to both anti-CTLA-4 and anti-PD1/PDL1 therapy, while the inhibition of IDO1 expression potentiates the response to both immunotherapy and chemotherapy [68,69]. Actually, IDO knockout mice with melanoma have longer survival than wild-type ones when treated with immunotherapy, while the combination of an IDO inhibitor with cytotoxic drugs like paclitaxel or with ICIs reduces tumor growth in mice with melanoma and BC $[68,69]$.

Based on these data, several IDO inhibitors have been developed. Among them, epacadostat (INCB024360)—an orally available, reversible competitive IDO1 inhibitor-showed potent anti-IDO1

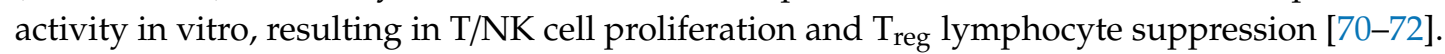

Results from a phase I trial, which haS enrolled 52 patients with advanced tumors, suggested that epacadostat has manageable side effects and exerts an adequate IDO1 inhibitor activity, with indirect pharmacodynamical data showing a significant reduction in plasma kynurenine levels [73]. The reported dose limiting toxicities (DLTs) were fatigue and pneumonitis; no objective responses were recorded, with stable disease (SD) as the best response in $13.5 \%$ of patients [73].

Subsequently, early phase studies combining epacadostat with other treatments were more promising. Data from the ECHO-202 and ECHO-204 Phase I/II studies showed a safe toxicity profile for the combination of epacadostat with pembrolizumab and nivolumab, respectively [74,75]. The most frequent adverse events (AEs) were skin rash and lipase elevation, with promising data regarding activity $[74,75]$. It is noteworthy, indeed, that ORRs of $55 \%$ for the combination of pembrolizumab and epacadostat and of $75 \%$ for the combination of nivolumab and epacadostat were achieved in the melanoma cohort with interesting, although lower, ORRs in other tumor types like head and neck $(\mathrm{H} \& \mathrm{~N})$ cancer, urothelial cancer and NSCLC $[71,75,76]$. 
Due to these encouraging results, a Phase III trial (ECHO-301) was conducted. It recruited 706 ICI-naïve patients with unresectable Stage III or IV melanoma [77]. They were randomized to receive epacadostat at $100 \mathrm{mg}$ orally twice daily plus pembrolizumab at $200 \mathrm{mg}$ every 3 weeks or a placebo plus pembrolizumab for up to 24 months [77]. This study's results were negative; indeed, with a median follow up of 12.4 months (IQR, 10.3-14.5), there were no differences in progression free survival (PFS) (HR, 1.00; 95\% CI, 0.83-1.21; one-sided $p=0.52$ ) or overall survival (OS) (median not reached in either group; HR, 1.13, CI, 0.86-1.49; one-sided $p=0.81$ ) [77]. The most recorded Grade 3 or worse toxicity was a lipase increase, in less than $5 \%$ of patients in both arms [77].

Several doubts regarding the ECHO-301 trial remain. The most relevant ones are if the dose used was sufficient to inhibit IDO1 activity in the TME (with pharmacodynamical data on IDO1 inhibition from Phase I trials only giving an indirect suggestion of activity) and, above all, if targeting only IDO1 is sufficient to control tryptophan catabolism or if the use of a dual inhibitor may be more successful in these patients [58].

The results of the ECHO-301 trial, however, were consistent with those reported in other Phase II and III trials conducted in different settings. In NSCLC patients (KEYNOTE-715-06/ECHO-306-06), the combination of epacadostat, pembrolizumab and platinum-based chemotherapy does not guarantee a benefit in ORR. In RCC (KEYNOTE-679/ECHO-302), no difference in ORRs were observed between pembrolizumab plus epacadostat compared to the standard of care-sunitinib or pazopanib. In recurrent or metastatic H\&N squamous cell carcinoma (KEYNOTE-669/ECHO-304), the combination of epacadostat and pembrolizumab was not more powerful but was less toxic than the EXTREME regimen [78].

Beyond epacadostat, new IDO inhibitors are under clinical development, such as navoximod (NLG-919), an oral dual IDO1 and TDO inhibitor, and BMS-986205, an irreversible IDO1 inhibitor [70].

Navoximod showed an ORR of only $11 \%$ in combination with atezolizumab in heavily pretreated patients, with a safe profile [79]. On the other hand, BMS-986205, in combination with nivolumab, achieved an ORR of $34 \%$ in the advanced bladder cancer cohort of a Phase I/II trial (NCT02658890), and a Phase III trial is ongoing in muscle-invasive bladder cancer patients [80].

Taken together, these results might suggest reconsidering the IDO inhibition strategy overall.

Indeed, off-target effects of IDO inhibition-such as the prolonged activation ofAhR, the iper-activation of the mTOR pathway and the alteration of the gut microbiota-might be responsible for the lack of efficacy of these compounds [58]. On the other hand, these off-target effects could be exploited to find new powerful combinations and to implement the research on predictive biomarkers to select the most suitable population [81].

See Table 3 for ongoing clinical trials targeting this pathway. 
Table 3. Selected ongoing clinical trials exploring the tryptophan-kynurenine-aryl (Trp-Kyn-AhR) pathway.

\begin{tabular}{|c|c|c|c|c|c|}
\hline Molecular Target & Agents & Phase & Indications & $\begin{array}{l}\text { Clinical Trial } \\
\text { Identifier }\end{array}$ & Status \\
\hline IDO-1 & $\begin{array}{l}\text { Epacadostat }+ \\
\text { pembrolizumab }\end{array}$ & II & $\begin{array}{l}\text { Muscle invasive } \\
\text { bladder urothelial } \\
\text { cancer }\end{array}$ & NCT03832673 & $\begin{array}{l}\text { Not yet } \\
\text { recruiting }\end{array}$ \\
\hline IDO-1 & $\begin{array}{l}\text { Epacadostat + } \\
\text { urvalumab }\end{array}$ & II & $\begin{array}{l}\text { Epstein-Barr } \\
\text { virus-positive } \\
\text { nasopharyngeal cancer }\end{array}$ & NCT04231864 & $\begin{array}{l}\text { Not yet } \\
\text { recruiting }\end{array}$ \\
\hline IDO-1 & $\begin{array}{l}\text { Epacadostat }+ \\
\text { embrolizumab }\end{array}$ & II & $\begin{array}{l}\text { Esophageal and gastric } \\
\text { tumor }\end{array}$ & NCT03196232 & Recruiting \\
\hline $\begin{array}{l}\text { IDO-1+ vaccines } \\
\text { (mesotelin } \\
\text { \&GM-CSF) }\end{array}$ & $\begin{array}{l}\text { Epacadostat }+ \\
\text { embrolizumab, + } \\
\text { RS-207 +/- } \\
\text { yclophospamide + } \\
\text { VAX }\end{array}$ & II & Pancreatic cancer & NCT03006302 & Recruiting \\
\hline IDO-1 & $\begin{array}{l}\text { Electroporetion }+/- \\
\text { Epacadostat }+ \\
\text { embrolizumab }\end{array}$ & II & $\begin{array}{l}\text { Head and neck }(\mathrm{H} \& \mathrm{~N}) \\
\text { cancers }\end{array}$ & NCT03823131 & Recruiting \\
\hline IDO-1 & $\begin{array}{l}\text { Nivolumab + } \\
\text { MS986205 }\end{array}$ & II & $\mathrm{H} \& \mathrm{~N}$ cancers & NCT03854032 & Recruiting \\
\hline IDO-1 & $\begin{array}{l}\text { Nivolumab + } \\
\text { MS986205 }\end{array}$ & II & $\begin{array}{l}\text { Endometrial carcinoma } \\
\text { and carcinosarcomas }\end{array}$ & NCT04106414 & Recruiting \\
\hline IDO-1 & $\begin{array}{l}\text { Neoadjuvantgemcitabine + } \\
\text { cisplatin }+/- \\
\text { Nivolumab +/- } \\
\text { BMS } 986205 . \\
\text { Post-surgery Nivolumab } \\
+/- \text { or BMS-986205 }\end{array}$ & III & $\begin{array}{l}\text { Muscle-invasive } \\
\text { bladder cancer }\end{array}$ & NCT03661320 & Recruiting \\
\hline
\end{tabular}

\subsection{The PI3K/AKT/mTOR Pathway}

The PI3K/AKT/mTOR pathway is physiologically involved in multiple functions, among which cell growth and survival, metabolism and motility are the most important [82]. Briefly, this pathway is activated by growth factors via receptor-tyrosine kinases (RTK); these kinases phosphorylate phosphatidylinositol-4,5-bisphosphate (PIP2) into phosphatidylinositol-3,4,5-trisphosphate (PIP3), inducing a cascade that eventually causes the recruitment and activation of phosphoinositide 3-kinase (PI3K), phosphoinositide-dependent kinase-1 (PDK1), mammalian target of rapamycin complex 2 (mTORC2) and AKT [82]. Then, AKT activates mTORC1, which induces cell proliferation and survival and increases cell metabolism [82]. PI3Ks are divided in three classes, among which Class I is the best characterized. It is further divided into Class IA PI3Ks (PI3K $\alpha$, PI3K $\beta$ and PI3K $\delta$ ) and Class IB PI3Ks $(\mathrm{PI} 3 \mathrm{~K} \gamma)$ [83].

Beyond its role in normal cells, this pathway is also dysregulated in about $30 \%$ of cancers, mediating tumor initiation, progression and drug resistance. Several mechanisms are involved, including activating mutations of RTK, PI3K, AKT or RAS or inactivating mutations of regulatory proteins like the phosphate and tensin homologue (PTEN) [84].

Recent studies have focused their attention on the role of the PI3K/AKT/mTOR pathway in the immune response. Preclinical data suggest that an alteration of the PI3K/AKT/mTOR pathway might promote an immunosuppressive response [85].

PTEN-mutant melanoma murine models showed a higher expression of immune suppressive cytokines, a decreased infiltration of $\mathrm{CD}^{+} \mathrm{T}$ cells and a reduced $\mathrm{T}$ cell-mediated cytotoxicity, while treatment with a PI3K $\beta$ inhibitor enhanced the response to both PD-1 and CTLA4 inhibitors [86]. PIK3CA-mutated bladder cancer patient-derived xenografts (PDXs) have a non-T-cell-inflamed phenotype, while the administration of BKM120, a pan PI3K inhibitor, induces immune activation and the response to PD-1 inhibitors [87].

Other evidence highlights that PDL-1 expression in tumor cells is also related to this pathway. Indeed, both PTEN-mutant triple negative breast cancer (TNBC) and CRC have higher expression of 
PDL-1. Moreover the use of a PI3K inhibitor or of rapamicin induces a reduction in PDL-1 expression in tumor cells [88-90].

The PI3K pathway also regulates MDSC differentiation. High PI3K $\delta$ expression is related to a higher number of $\mathrm{FOXP3}^{+} \mathrm{T}_{\text {reg }}$ cells, while the use of an inhibitor of this pathway reduces $\mathrm{T}_{\text {reg }}$ cells without affecting $\mathrm{CD} 8^{+}$TILs and reduces tumor growth [91-93].

Lastly, preclinical data suggest that the PI3K/AKT pathway is involved in the metabolic shift (from glycolysis to oxidative phosphorylation) that converts effector CD8 ${ }^{+} \mathrm{T}$ cells to memory T cells [94] and regulates the tumor associated macrophages' (TAMs') switch between immune stimulation and immune suppression [95].

This pathway has already been targeted therapeutically on the basis of its pleiotropic role in several malignancies. mTOR inhibitors, PI3K inhibitors (PI3Ki), dual PI3K-mTOR inhibitors and AKT inhibitors are approved in different settings such as advanced RCC (temsirolimus and everolumus), advanced ER+ BC (alpelisib and everolimus) and chronic lymphatic leukemia (CLL) (idelalisib) [84].

Nevertheless, its role in the immune response has not been exploited until recently.

New early phase studies with combinations of ICIs and PI3k/AKT/mTOR inhibitors aim at enhancing the immune response based on the aforementioned strong preclinical rationale. Preliminary data from a Phase I trial show that ipatasertib, an AKT inhibitor, added to atezolizumab and paclitaxel or nab-paclitaxel as a first-line treatment in TNBC guarantees an ORR of 73\% $(95 \% \mathrm{CI}, 53-88)$ regardless of PD-L1 status or PIK3CA/AKT1/PTEN alteration status. Moreover, the toxicity profile was acceptable, with Grade $\geq 3$ AEs recorded in $54 \%$ of patients, the most frequent all-grade AEs being diarrhea ( $88 \%$; with a grade $\geq 3,19 \%)$ and rash $(69 \%$; with a grade $\geq 3,27 \%)$ [96]. A Phase III study is ongoing in these patients (NCT04177108).

Other trials are actually combining drugs that target this pathway with immune checkpoint inhibitors alone (NCT03131908) or in combinations with other compounds (NCT03772561). Among them, a Phase I/II trial is exploring a PI3K inhibitor with nivolumab and ipilimumab (NCT04317105) in PI3K/AKT-mutated solid tumors, while a combination of Nab-rapamycin and nivolumab is under development in advanced sarcoma (NCT03190174) (Table 4).

Table 4. Selected ongoing clinical trials exploring the PI3K/AKT pathway.

\begin{tabular}{clcccc}
\hline $\begin{array}{c}\text { Molecular } \\
\text { Target }\end{array}$ & \multicolumn{1}{c}{ Agents } & Phase & Indications & $\begin{array}{c}\text { Clinical Trial } \\
\text { Identifier }\end{array}$ & Status \\
\hline $\begin{array}{c}\text { AKT + PARP+ } \\
\text { PDL-1 }\end{array}$ & $\begin{array}{l}\text { AZD5363 + } \\
\text { laparib }+ \\
\text { urvalumab }\end{array}$ & I & Advanced solid tumors & NCT03772561 & Recruiting \\
\hline $\begin{array}{c}\text { AKT+ } \\
\text { PDL-1 }\end{array}$ & $\begin{array}{l}\text { Paclitaxel +/- } \\
\text { patasertib +/- } \\
\text { tezolizumab }\end{array}$ & III & TNBC & NCT04177108 & Recruiting \\
\hline $\begin{array}{l}\text { PI3K+ } \\
\text { PD-1+CLTA4 }\end{array}$ & $\begin{array}{l}\text { Copanlisib }+ \\
\text { ivolumab +/- } \\
\text { pilimumab }\end{array}$ & I/II & PI3K/AKT-mutated solid tumors & NCT04317105 & Not yet \\
\hline PIK3b+ PD-1 & $\begin{array}{l}\text { GSK2636771 + } \\
\text { embrolizumab }\end{array}$ & I/II & PTEN-deficient melanoma \\
\hline PIK3+PD-1 & $\begin{array}{l}\text { Duvelisib + } \\
\text { embrolizumab }\end{array}$ & I/II & Head and neck cancer & NCT03131908 & Recruiting \\
\hline mTOR+PD1 & $\begin{array}{l}\text { ABI-009 } \\
\text { (Nab-rapamycin) }+ \\
\text { ivolumab }\end{array}$ & I/II & Advanced sarcoma & NCT03190174 & Recruiting \\
\hline
\end{tabular}

\subsection{Targeting Tumor-Associated Macrophages}

Tumor-associated macrophages (TAMs) are fundamental components of the microenvironment of solid tumors. TAMs express immune checkpoint modulators including PD-L1 and chemokines such as CCL17, CCL22, CXCL10 and IL-8, which attract $\mathrm{T}_{\text {reg }}$ s to tumor sites, downregulating 
the immune-response $[97,98]$. Although the main population of TAMs is immunosuppressive M2 macrophages, TAMs can be re-programmed into M1-type helper macrophages to enhance the antitumor effects of checkpoint inhibitors [99].

The first and most widely used therapeutic macrophage-based strategy has been TAM depletion from tumor sites via the inhibition of colony stimulating factor- $1 /$ colony stimulating factor- 1 receptor (CSF-1/CSF-1R) and CCL2/CCR2 inhibition [100,101]. Despite interesting pre-clinical results in mouse models, this strategy has failed to show activity in clinical trials to date [102].

Other explored strategies are the inhibition of PI3K $\gamma$, CCL5-CCR5 and CXCR2 but also the use of antibodies binding the macrophage-derived protein MARCO [103]. Moreover, drugs that antagonize the CD47-SIRP $\alpha$ pathway are under development; CD47 is a transmembrane protein both on normal and cancer cells. Its signaling is based on an anti-phagocytic response, inducing resistance to phagocytosis by macrophages. Magrolimab is a first-in-class CD47 inhibitor that has been tested in a clinical trial, but several other agents are under study now [104-106]. Selected ongoing trials with drugs targeting macrophage checkpoints are listed in Table 5.

Table 5. Selected ongoing clinical trials exploring macrophage checkpoint blockade.

\begin{tabular}{|c|c|c|c|c|c|}
\hline $\begin{array}{c}\text { Molecular } \\
\text { Target }\end{array}$ & Agents & Phase & Indications & $\begin{array}{c}\text { Clinical Trial } \\
\text { Identifier }\end{array}$ & Status \\
\hline CSF-1R & $\begin{array}{l}\text { SNDX-6532+ } \\
\text { Durvalumab }\end{array}$ & II & Cholangiocarcinoma & NCT04301778 & Recruiting \\
\hline CSF-1R & $\begin{array}{c}\text { Cabiralizumab + } \\
\text { Nivolumab }\end{array}$ & II & $\begin{array}{l}\text { Peripheral T cell } \\
\text { lymphoma }\end{array}$ & NCT03927105 & Recruiting \\
\hline CSF-1R & $\begin{array}{l}\text { DCC-3014 + } \\
\text { Avelumab }\end{array}$ & $\mathrm{Ib}$ & High grade sarcomas & NCT04242238 & Recruiting \\
\hline CXCR2 & $\begin{array}{c}\text { AZD5069+ } \\
\text { Enzalutamide }\end{array}$ & II & $\begin{array}{l}\text { Metastatic castration } \\
\text { resistant prostate cancer }\end{array}$ & NCT03177187 & Recruiting \\
\hline MDSCs & $\begin{array}{c}\text { SX-682 + } \\
\text { Pembrolizumab }\end{array}$ & I & Melanoma & NCT03161431 & Recruiting \\
\hline CCR5 & Leronlimab (PRO 140) + carboplatin & $\mathrm{Ib} / \mathrm{II}$ & TNBC & NCT03838367 & Recruiting \\
\hline CD47 & SGN-CD47M & I & Solid tumors & NCT03957096 & Recruiting \\
\hline CD47 & $\begin{array}{l}\text { Magrolimab + } \\
\text { chemotherapy }\end{array}$ & I & $\begin{array}{l}\text { B-cell Non-Hodgkin's } \\
\text { lymphoma }\end{array}$ & NCT02953509 & Recruiting \\
\hline
\end{tabular}

\section{Immune-Metabolism Dysregulation at Host Level}

The metabolism of the host itself is physiologically involved in the immune response and can play a role in both de novo and acquired resistance to ICIs [10]. Some characteristics, like body weight and gender, seem to impact the immune response, but the data are still few and controversial [11,107]. On the other hand, the composition of the microbiome affects the efficacy of ICIs and is also an intriguing target for potentially building up and fostering the immune response in different malignancies $[108,109]$.

\subsection{Obesity Paradox}

Excess body weight is a major public health problem worldwide. Indeed, an elevated body mass index (BMI) has been associated with reduced cancer survival, with ten obesity-related cancers listed by World Cancer Research Fund [110,111].

However, some recently published studies demonstrated that, among patients with a diagnosis of cancer, an elevated BMI is unexpectedly associated with improved survival, in the so-called "obesity paradox" [112-118]. The obesity paradox has been postulated in different metastatic and non-metastatic settings such as in patients with RCC and CRC receiving surgery $[112,114,117]$ and patients affected by lymphoma who have underwent autologous hematopoietic cell transplantation [119]. Interestingly, an analysis of a cohort of 423 metastatic melanoma patients suggested a positive association between the benefit from ICIs and BMI, but it was burdened by several confounders [107]. Moreover, in a retrospective analysis of 55 NSCLC patients treated with immunotherapy, a higher BMI was related to a longer OS, while hypercholesterolemia was related to a longer PFS [120]. 
A possible explanation for the obesity paradox might be the immune-suppressed phenotype frequently observed in obese patients as a result of chronic inflammation, with a decrease in natural killer T cells, $\mathrm{CD}^{+} \mathrm{T}$ cells and M2 macrophages and an increase in PD-1 expression [121].

Moreover, the pharmacokinetics of ICIs are extremely different from those of classical cytotoxic agents, as they are metabolized, above all, in the liver, and their metabolism might be compromised in obese patients due to the altered metabolism of free fatty acids and the presence of pro-inflammatory cytokines $[107,121,122]$. A plausible altered clearance, together with the diffuse use of flat doses in ICI administration and the lack of data analyzing the pharmacokinetics in patients with high BMIs make the relationship between BMI and the ICI response even more complex [107].

Lastly, some methodological considerations should be addressed. First, the time-point at which the BMI was determined during these studies is important: before the diagnosis, peri-diagnosis or post diagnosis (usually 12 months after the treatment's start) [110,118]. Wu et al. showed a better survival outcome for patients who were overweight post-treatment but not in patients with a high pre-diagnosis BMI [123]. Age is another aspect to be considered as a potential bias factor. In fact, both Brunner et al. and Navarro et al. observed that the obesity paradox was confirmed only in younger patients and not in patients older than 60 years $[115,124]$. Another limitation of the use of BMI is that it does not differentiate between lean mass and fat mass. In a study enrolling 175 patients with breast, gynecological, lung, gastrointestinal and H\&N carcinomas, the obesity paradox was confirmed only using BMI and not when obesity was defined using other indices such as the fat-free mass index or fat mass index [125].

\subsection{Gender Effect}

Sex chromosomes and hormones are involved in the regulation of both local and systemic determinants of carcinogenesis, such as cancer-initiating cells, the composition of the TME, cell metabolism and the immune system's functions [126].

One of the most important differences between male and female bodies is related to the percentages of lean and fat mass: lean, and metabolically active, mass is responsible for $80 \%$ of a man's and $65 \%$ of a woman's body mass, although it is not a variable considered in the dosing of standard chemotherapy or ICIs [127].

Differences in the physiological immune response can justify a distinct benefit from ICIs in male and female populations. Several meta-analyses evaluated whether there were gender-related differences in the ICI response [11,126,128-131].

Four of them suggested that anti-CTLA-4 treatment might guarantee a longer survival in men but not in women $[11,128,131,132]$.

However, the suggested absence of benefit from anti-CTLA-4 in female patients needs to be interpreted really carefully. On the one hand, the early phase of the immune response is stronger in women, both in terms of more efficient APCs and a wider population CD4 + T cells [133].

On the other hand, these results may be specific for some tumor types, not being confirmed in a population of women with melanoma [126,131].

Moreover, these meta-analyses rely on published results and not on raw data, making it difficult to control bias in the selection criteria and confounding factors like lifestyle or attitude and compliance with treatment [134].

As demonstrated by Han et al. with a rigorous computational approach, there is an unexpected divergent pattern in sex-associated differences across different cancer types (melanoma and lung cancer) [135].

Lastly, a great deal of interest was raised in biomarkers of response. Some differences based on gender have been highlighted in the neoantigen load, PD-L1 protein expression and tumor mutational burden (TMB), as well as in other immune checkpoints (e.g., LAG3 and IDO1) and the distribution of immune cell populations (active CD4/CD8 T cells, memory CD4/CD8 T cells and $\mathrm{T}_{\text {reg }}$ cells) [135]. 
These results, taken together, suggest prospective clinical trials stratified by gender in the randomization process.

\subsection{Microbiota}

The intestinal microbiota has been estimated to contain more than 100 trillion bacteria [136]. The interactions between resident microbes and the immune system have been largely explored [137].

Zitvogel et al. hypothesized that the microbiota plays a role in antitumor immunosurveillance through the cross-reactions between the microbiota and tumor antigens, the production of bacterial metabolites that might have systemic modulatory effects and the stimulation of pattern-recognition receptors (PRRs) [138].By activating PRRs, mostly expressed by innate immune effectors, microbes can stimulate the production of cytokines and interferons, which can determine the tendency to inflammatory and immunostimulatory or, on the other hand, to immunosuppressive reactions [138].

The composition of the intestinal microbiota in mouse models seems to affect the efficacy of ICIs $[109,139]$. In particular, Sivan et al. showed that genetically identical mice derived from two different mouse facilities and with differences in their commensal microbes showed a distinct tumor growth and response to immunotherapy, while cohousing leveled those differences [109].

Several authors have also confirmed these hypotheses in human species, reporting that a particular gut microbiota composition could affect the response to immunotherapy in different tumors such as melanoma, NSCLC, RCC, and urothelial carcinoma [108,140,141]. Frankel et al. published the first report on human gut microbiota metagenomic and metabolomic profiling in melanoma patients treated with immunotherapy, showing that ICI responders were enriched for Bacteroidescaccae [142]. A wide-diversified microbiota seems to be more frequent in patients with a great benefit from the treatment, with a direct correlation between a large diversification of the microbiota and a higher number of T cell numbers in both the blood and TME [108,140,141].

An interesting field of discussion is how concomitant medications can modify the gut microbiota and, eventually, the response to ICIs.

The associations between antibiotic (ATB) usage and the efficacy of immunotherapy was investigated in different studies with contradictory results [139,143-145]. In the retrospective study of Derosa et al., 121 patients with RCC and 239 patients with NSCLC were evaluated [144]. Patients treated with recent ATB therapy (30 or 60 days before the administration of ICIs) were compared with patients who did not receive ATBs, with the results highlighting a shorter PFS and OS for those patients receiving an ATB in both the RCC and NSCLC groups [144].

Furthermore, the combination of ATBs and proton pump inhibitors (PPI) has also been associated with gut dysbiosis, decreased bacterial richness, and the promotion of T-cell tolerance [146].

Chalabi et al. recently published an analysis including 1500 patients from randomized, controlled trials and first reported a detrimental effect of PPI and ATBs on ICI efficacy in patients with advanced NSCLC [146].

It seems that ATB treatment may reduce the efficacy of ICIs, undermining the wide array of bacterial species, each one with a distinct metabolomic and metagenomic profile [108,140,141].

Similarly, PPI affect the gut microbiome; it is suggested that they directly increase stomach $\mathrm{pH}$, whose role is, physiologically, to prevent infections from food-derived and oral bacteria [147].

Lastly, the composition of the microbiota can also affect the resistance to immune-related adverse events (IrAEs) [148-150]. A study demonstrated that the presence of bacteria belonging to the Bacteroidetes phylum in the intestinal microbiota is correlated with resistance to the development of ICI-induced colitis [148]. In a prospective study, a baseline gut microbiota enriched with Faecalibacterium and other Firmicutes is associated with both a better clinical response to ipilimumab and a higher risk of ipilimumab-induced colitis [149].

To date, the available studies have been too heterogeneous, above all because it has been very difficult to use a standardized methodology in this field; therefore, further investigation regarding the role of the gut microbiota in ICIs' resistance (and response) mechanisms are needed. 
A promising therapeutic approach using the microbiota seems to be fecal microbiome transplantation (FMT), basically, a transplant of the feces from immune-responder patients.

In preclinical models, FMT in germ-free mice led to improved tumor control and a higher response to immunotherapy $[108,140,141]$. Phase I and II trials in melanoma patients are ongoing (NCT03353402 and NCT03341143) exploiting FMT to revert immune resistance. An ongoing early Phase 1 trial (NCT03686202) explores another approach, alternative to fecal transplantation-microbial ecosystem therapeutics (MET), a defined mixture of pure live cultures of intestinal bacterial isolates from a stool sample of a healthy donor administered with ICIs.

Other strategies such as oral supplementation with specific bacteria or antibiotic therapy might modify the intestinal microbiota in order to enhance the effect of anticancer therapies and, hopefully, in the future, to overcome resistance to ICIs $[109,140]$.

\section{Conclusions and Future Perspectives}

The therapeutic algorithm has been massively changed by the introduction of ICIs for several malignancies (from metastatic melanoma and advanced NSCLC to RCC, urothelial cancers and squamous cell cancer of the H\&N, and from hematologic cancers, such as classic Hodgkin's lymphoma, to rare tumors such as Merkel cell carcinoma) with, eventually, a broad-range approval for solid tumors with microsatellite instability (MSI-H) and mismatch repair deficiency.

However, in this evolving field, primary and secondary resistance are an emerging issue [10]. Understanding de novo resistance may allow the discovery of predictive biomarkers of response for increasing response rates in tumors that are theoretically "cold" (i.e., intrinsically resistant), while tackling acquired resistance could prolong clinical benefit in patients who are initially responders but then progress [10].

As described above, different metabolic pathways are involved, and most of them are interdependent. Alterations of the TME, as well as mutations of cancer-related pathways, interact with host factors such gender, BMI and, above all, variations in the microbiota, modifying the immune response and, eventually, the benefit from ICIs [151,152]. These metabolic alterations are interesting targets to overcome immune resistance, but although some of them have yet achieved regulatory approval for modifying therapeutic algorithms, for others, the results are frankly disappointing or at least controversial $[49,51,77]$.

Several points need to be taken into account when designing new clinical trials and treating patients with ICIs.

- Are there any predictive factors that should be taken into account for tailoring immunotherapy?

1. PD-L1 expression, microsatellite instability and the tumor mutational burden have already been demonstrated to be useful biomarkers in specific settings; however, their sensitivity is limited, and their effectiveness has been confirmed only in specific types of tumor [153].

2. Other predictive factors such as the genomic signatures and metabolic profiles associated with ICI resistance are under preclinical and clinical evaluation, and some of them have shown encouraging results [154]. The presence of mutations of Janus kinase 2 (JAK2), beta2-microglobulin and serine/threonine kinase 11 (STK11) are some of the alterations that have recently emerged as potential predictors of low responsiveness to ICIs [155-157].

3. Heterozygosity in the HLA class I genotype, a characteristic that facilitates the presentation of a broader set of tumor antigens to $\mathrm{T}$ cells, is another possible response biomarker that has been demonstrated to confer a higher responsivity to ICIs in cancer patients $[158,159]$.

4. A dynamic research area aims at finding predictors of response, specifically for the combination of antiangiogenics and ICIs. In patients with HCC treated with the combination of bevacizumab and atezolizumab, there was a correlation between the expression of a signature of pre-existing immunity, including PD-L1 $(H R=0.42)$ and T effector markers $(\mathrm{HR}=0.46)$, and a longer PFS while Notch pathway activation correlated with a worse clinical 
outcome [160]. Interestingly, higher levels of VEGF receptor $2(\mathrm{HR}=0.36), \mathrm{T}_{\text {regs }}(\mathrm{HR}=0.35)$, myeloid inflammation $(\mathrm{HR}=0.43)$ and triggering receptor expressed on myeloid cells 1 (TREM1)/MDSC signatures ( $\mathrm{HR}=0.43$ ) were predictive of a longer PFS in patients treated with atezolizumab and bevacizumab than in those who had received the ICI alone, suggesting a possible role for these markers [160].

5. Among host factors, the gut microbiome composition is another potential predictor of response. This is particularly interesting because the determination of the gut microbiome does not require invasive procedures such as tumor biopsies $[108,140]$.

- Considering host factor relevance, how should we modify both clinical trial designs and, eventually, everyday practice?

1. Prospective clinical trials should consider a gender-based randomization approach. This may significantly contribute to a deeper comprehension of the role of gender in the antitumor activity of ICIs and help in the identification of predictors of response/resistance and toxicities to ICIs, differently expressed in men and women.

2. Baseline BMI, not only performance status (PS), should be considered as a stratification factor in future ICI trials.

3. The effect of antibiotics and proton pump inhibitors on the response to ICI therapy warrants further investigation. Physicians should carefully evaluate the need for co-medications such as antibiotics or proton pump inhibitors during immunotherapy.

In conclusion, metabolic pathways play a crucial, although not fully understood, role in both intrinsic and acquired resistance to ICIs.

The reformulation of prospective clinical trials, taking into account host factors, and the identification of both new predictive factors and new compounds tackling immune metabolism might be the successful tools for comprehending and overcoming resistance in the immunotherapy era.

Author Contributions: G.G., E.G. and G.V. conceptualization and methodology. All authors contributed to manuscript writing and reviewing. G.G. and E.G. final editing. All authors have read and agree to the published version of the manuscript.

Funding: This research was funded by "progetto OVERHEAD vincolo 1982" to GV.

Conflicts of Interest: G.G., E.G., S.G., G.S., V.T., M.T. declare no conflict of interest. G.V. reports speaking honoraria from PharmaMar, AstraZeneca, Roche, Clovis and GSK-Tesaro and travel grants from GSK-Tesaro and PharmaMar and has been part of the advisory boards of Tesaro, Amgen and PharmaMar outside of the submitted work.

\section{References}

1. Albittar, A.A.; Alhalabi, O.; Glitza Oliva, I.C. Immunotherapy for Melanoma. Adv. Exp. Med. Biol. 2020, 1244, 51-68. [CrossRef] [PubMed]

2. Siefker-Radtke, A.O.; Apolo, A.B.; Bivalacqua, T.J.; Spiess, P.E.; Black, P.C. Immunotherapy with Checkpoint Blockade in the Treatment of Urothelial Carcinoma. J. Urol. 2018, 199, 1129-1142. [CrossRef] [PubMed]

3. Peinemann, F.; Unverzagt, S.; Hadjinicolaou, A.V.; Moldenhauer, I. Immunotherapy for metastatic renal cell carcinoma: A systematic review. J. Evid. Based Med. 2019, 12, 253-262. [CrossRef] [PubMed]

4. Bair, S.M.; Mato, A.; Svoboda, J. Immunotherapy for the Treatment of Hodgkin Lymphoma: An Evolving Paradigm. Clin. Lymphoma Myeloma Leuk. 2018, 18, 380-391. [CrossRef] [PubMed]

5. Borghaei, H.; Langer, C.J.; Gadgeel, S.; Papadimitrakopoulou, V.A.; Patnaik, A.; Powell, S.F.; Gentzler, R.D.; Martins, R.G.; Stevenson, J.P.; Jalal, S.I.; et al. 24-Month Overall Survival from KEYNOTE-021 Cohort G: Pemetrexed and Carboplatin with or without Pembrolizumab as First-Line Therapy for Advanced Nonsquamous Non-Small Cell Lung Cancer. J. Thorac. Oncol. 2019, 14, 124-129. [CrossRef]

6. Miñana López, B.; Villacampa Aubá, F.; de Fata Chillón, F.R.; Ancizu Markert, F.J.; García Cortés, A.; Doménech López, P.; Chiva San Román, S.; Velis Campillo, J.M.; Díez-Caballero Alonso, F.; Robles García, J.E.; et al. Immunotherapy in castration resistant prostate cancer. Arch. Esp. Urol. 2018, 71, 685-695. 
7. Seto, T.; Sam, D.; Pan, M. Mechanisms of Primary and Secondary Resistance to Immune Checkpoint Inhibitors in Cancer. Med. Sci. 2019, 7, 14. [CrossRef]

8. Eggermont, A.M.; Chiarion-Sileni, V.; Grob, J.J.; Dummer, R.; Wolchok, J.D.; Schmidt, H.; Hamid, O.; Robert, C.; Ascierto, P.A.; Richards, J.M.; et al. Adjuvant ipilimumab versus placebo after complete resection of high-risk stage III melanoma (EORTC 18071): A randomised, double-blind, phase 3 trial. Lancet Oncol. 2015, 16, 522-530. [CrossRef]

9. Eggermont, A.M.; Chiarion-Sileni, V.; Grob, J.J.; Dummer, R.; Wolchok, J.D.; Schmidt, H.; Hamid, O.; Robert, C.; Ascierto, P.A.; Richards, J.M.; et al. Prolonged Survival in Stage III Melanoma with Ipilimumab Adjuvant Therapy. N. Engl. J. Med. 2016, 375, 1845-1855. [CrossRef]

10. Syn, N.L.; Teng, M.W.L.; Mok, T.S.K.; Soo, R.A. De-novo and acquired resistance to immune checkpoint targeting. Lancet Oncol. 2017, 18, e731-e741. [CrossRef]

11. Conforti, F.; Pala, L.; Bagnardi, V.; De Pas, T.; Martinetti, M.; Viale, G.; Gelber, R.D.; Goldhirsch, A. Cancer immunotherapy efficacy and patients' sex: A systematic review and meta-analysis. Lancet Oncol. 2018, 19, 737-746. [CrossRef]

12. Kwon, H.; Lin, C.Y.; Chung, D.; Li, X.; Li, Z. Sex as a predictor of response to cancer immunotherapy. Lancet Oncol. 2018, 19, e379. [CrossRef]

13. Baffy, G. Gut Microbiota and Cancer of the Host: Colliding Interests. Adv. Exp. Med. Biol. Biol. 2020, 1219, 93-107. [CrossRef]

14. Popovic, G.; Harhara, T.; Pope, A.; Al-Awamer, A.; Banerjee, S.; Bryson, J.; Mak, E.; Lau, J.; Hannon, B.; Swami, N.; et al. Patient-Reported Functional Status in Outpatients with Advanced Cancer: Correlation With Physician-Reported Scores and Survival. J. Pain Symptom Manag. 2018, 55, 1500-1508. [CrossRef]

15. Fritz, J.M.; Lenardo, M.J. Development of immune checkpoint therapy for cancer. J. Exp. Med. 2019, 216, 1244-1254. [CrossRef]

16. Lind, D.S. Arginine and cancer. J. Nutr. 2004, 134, 2837S-2841S. [CrossRef]

17. Munder, M. Arginase: An emerging key player in the mammalian immune system. Br. J. Pharmacol. 2009, 158, 638-651. [CrossRef]

18. Gubser, P.M.; Bantug, G.R.; Razik, L.; Fischer, M.; Dimeloe, S.; Hoenger, G.; Durovic, B.; Jauch, A.; Hess, C. Rapid effector function of memory CD8+ T cells requires an immediate-early glycolytic switch. Nat. Immunol. 2013, 14, 1064-1072. [CrossRef]

19. Zheng, Y.; Delgoffe, G.M.; Meyer, C.F.; Chan, W.; Powell, J.D. Anergic T cells are metabolically anergic. J. Immunol. 2009, 183, 6095-6101. [CrossRef]

20. Chang, C.H.; Qiu, J.; O’Sullivan, D.; Buck, M.D.; Noguchi, T.; Curtis, J.D.; Chen, Q.; Gindin, M.; Gubin, M.M.; van der Windt, G.J.; et al. Metabolic Competition in the Tumor Microenvironment Is a Driver of Cancer Progression. Cell 2015, 162, 1229-1241. [CrossRef]

21. Ho, P.C.; Bihuniak, J.D.; Macintyre, A.N.; Staron, M.; Liu, X.; Amezquita, R.; Tsui, Y.C.; Cui, G.; Micevic, G.; Perales, J.C.; et al. Phosphoenolpyruvate Is a Metabolic Checkpoint of Anti-tumor T Cell Responses. Cell 2015, 162, 1217-1228. [CrossRef] [PubMed]

22. Galliverti, G.; Wullschleger, S.; Tichet, M.; Murugan, D.; Zangger, N.; Horton, W.; Korman, A.J.; Coussens, L.M.; Swartz, M.A.; Hanahan, D. Myeloid Cells Orchestrate Systemic Immunosuppression, Impairing the Efficacy of Immunotherapy against HPV. Cancer Immunol. Res. 2020, 8, 131-145. [CrossRef] [PubMed]

23. Rudd, C.E. A new perspective in cancer immunotherapy: PD-1 on myeloid cells takes center stage in orchestrating immune checkpoint blockade. Sci. Immunol. 2020, 5. [CrossRef] [PubMed]

24. Hatfield, S.M.; Kjaergaard, J.; Lukashev, D.; Schreiber, T.H.; Belikoff, B.; Abbott, R.; Sethumadhavan, S.; Philbrook, P.; Ko, K.; Cannici, R.; et al. Immunological mechanisms of the antitumor effects of supplemental oxygenation. Sci. Transl. Med. 2015, 7, 277ra230. [CrossRef]

25. Linnemann, C.; Schildberg, F.A.; Schurich, A.; Diehl, L.; Hegenbarth, S.I.; Endl, E.; Lacher, S.; Müller, C.E.; Frey, J.; Simeoni, L.; et al. Adenosine regulates CD8 T-cell priming by inhibition of membrane-proximal T-cell receptor signalling. Immunology 2009, 128, e728-e737. [CrossRef]

26. Fredholm, B.B.; IJzerman, A.P.; Jacobson, K.A.; Linden, J.; Müller, C.E. International Union of Basic and Clinical Pharmacology. LXXXI. Nomenclature and classification of adenosine receptors-an update. Pharmacol. Rev. 2011, 63, 1-34. [CrossRef] 
27. Csóka, B.; Németh, Z.H.; Duerr, C.U.; Fritz, J.H.; Pacher, P.; Haskó, G. Adenosine receptors differentially regulate type 2 cytokine production by IL-33-activated bone marrow cells, ILC2s, and macrophages. FASEB J. 2018, 32, 829-837. [CrossRef]

28. Antonioli, L.; Fornai, M.; Blandizzi, C.; Pacher, P.; Haskó, G. Adenosine signaling and the immune system: When a lot could be too much. Immunol. Lett. 2019, 205, 9-15. [CrossRef]

29. Yago, T.; Tsukamoto, H.; Liu, Z.; Wang, Y.; Thompson, L.F.; McEver, R.P. Multi-Inhibitory Effects of A2A Adenosine Receptor Signaling on Neutrophil Adhesion Under Flow. J. Immunol. 2015, 195, 3880-3889. [CrossRef]

30. McColl, S.R.; St-Onge, M.; Dussault, A.A.; Laflamme, C.; Bouchard, L.; Boulanger, J.; Pouliot, M. Immunomodulatory impact of the A2A adenosine receptor on the profile of chemokines produced by neutrophils. FASEB J. 2006, 20, 187-189. [CrossRef]

31. Lokshin, A.; Raskovalova, T.; Huang, X.; Zacharia, L.C.; Jackson, E.K.; Gorelik, E. Adenosine-mediated inhibition of the cytotoxic activity and cytokine production by activated natural killer cells. Cancer Res. 2006, 66, 7758-7765. [CrossRef] [PubMed]

32. Allard, B.; Pommey, S.; Smyth, M.J.; Stagg, J. Targeting CD73 enhances the antitumor activity of anti-PD-1 and anti-CTLA-4 mAbs. Clin. Cancer Res. 2013, 19, 5626-5635. [CrossRef] [PubMed]

33. Young, A.; Ngiow, S.F.; Barkauskas, D.S.; Sult, E.; Hay, C.; Blake, S.J.; Huang, Q.; Liu, J.; Takeda, K.; Teng, M.W.L.; et al. Co-inhibition of CD73 and A2AR Adenosine Signaling Improves Anti-tumor Immune Responses. Cancer Cell 2016, 30, 391-403. [CrossRef] [PubMed]

34. Vigano, S.; Alatzoglou, D.; Irving, M.; Ménétrier-Caux, C.; Caux, C.; Romero, P.; Coukos, G. Targeting Adenosine in Cancer Immunotherapy to Enhance T-Cell Function. Front. Immunol. 2019, 10, 925. [CrossRef]

35. Häusler, S.F.; Montalbán del Barrio, I.; Strohschein, J.; Chandran, P.A.; Engel, J.B.; Hönig, A.; Ossadnik, M.; Horn, E.; Fischer, B.; Krockenberger, M.; et al. Ectonucleotidases CD39 and CD73 on OvCA cells are potent adenosine-generating enzymes responsible for adenosine receptor 2A-dependent suppression of $\mathrm{T}$ cell function and NK cell cytotoxicity. Cancer Immunol. Immunother. 2011, 60, 1405-1418. [CrossRef]

36. Young, A.; Mittal, D.; Stagg, J.; Smyth, M.J. Targeting cancer-derived adenosine: New therapeutic approaches. Cancer Discov. 2014, 4, 879-888. [CrossRef]

37. Vijayan, D.; Young, A.; Teng, M.W.L.; Smyth, M.J. Targeting immunosuppressive adenosine in cancer. Nat. Rev. Cancer 2017, 17, 765. [CrossRef]

38. Overman, M.J.; LoRusso, P.; Strickler, J.H.; Patel, S.P.; Clarke, S.J.; Noonan, A.M.; Prasanna, T.; Amin, M.A.; Nemunaitis, J.J.; Desai, J.; et al. Safety, efficacy and pharmacodynamics (PD) of MEDI9447 (oleclumab) alone or in combination with durvalumab in advanced colorectal cancer (CRC) or pancreatic cancer (panc). J. Clin. Oncol. 2018, 36, 4123. [CrossRef]

39. Fukumura, D.; Kloepper, J.; Amoozgar, Z.; Duda, D.G.; Jain, R.K. Enhancing cancer immunotherapy using antiangiogenics: Opportunities and challenges. Nat. Rev. Clin. Oncol. 2018, 15, 325-340. [CrossRef]

40. Facciabene, A.; Peng, X.; Hagemann, I.S.; Balint, K.; Barchetti, A.; Wang, L.P.; Gimotty, P.A.; Gilks, C.B.; Lal, P.; Zhang, L.; et al. Tumour hypoxia promotes tolerance and angiogenesis via CCL28 and T(reg) cells. Nature 2011, 475, 226-230. [CrossRef]

41. Facciabene, A.; De Sanctis, F.; Pierini, S.; Reis, E.S.; Balint, K.; Facciponte, J.; Rueter, J.; Kagabu, M.; Magotti, P.; Lanitis, E.; et al. Local endothelial complement activation reverses endothelial quiescence, enabling t-cell homing, and tumor control during t-cell immunotherapy. Oncoimmunology 2017, 6, e1326442. [CrossRef] [PubMed]

42. Han, L.Y.; Fletcher, M.S.; Urbauer, D.L.; Mueller, P.; Landen, C.N.; Kamat, A.A.; Lin, Y.G.; Merritt, W.M.; Spannuth, W.A.; Deavers, M.T.; et al. HLA class I antigen processing machinery component expression and intratumoral T-Cell infiltrate as independent prognostic markers in ovarian carcinoma. Clin. Cancer Res. 2008, 14, 3372-3379. [CrossRef] [PubMed]

43. Joyce, J.A.; Fearon, D.T. T cell exclusion, immune privilege, and the tumor microenvironment. Science 2015, 348, 74-80. [CrossRef] [PubMed]

44. Voron, T.; Colussi, O.; Marcheteau, E.; Pernot, S.; Nizard, M.; Pointet, A.L.; Latreche, S.; Bergaya, S.; Benhamouda, N.; Tanchot, C.; et al. VEGF-A modulates expression of inhibitory checkpoints on CD8+ T cells in tumors. J. Exp. Med. 2015, 212, 139-148. [CrossRef] [PubMed] 
45. Gabrilovich, D.; Ishida, T.; Oyama, T.; Ran, S.; Kravtsov, V.; Nadaf, S.; Carbone, D.P. Vascular endothelial growth factor inhibits the development of dendritic cells and dramatically affects the differentiation of multiple hematopoietic lineages in vivo. Blood 1998, 92, 4150-4166. [CrossRef]

46. Khan, K.A.; Kerbel, R.S. Improving immunotherapy outcomes with anti-angiogenic treatments and vice versa. Nat. Rev. Clin. Oncol. 2018, 15, 310-324. [CrossRef]

47. Chen, D.S.; Hurwitz, H. Combinations of Bevacizumab with Cancer Immunotherapy. Cancer J. 2018, 24, 193-204. [CrossRef]

48. Reck, M.; Mok, T.S.K.; Nishio, M.; Jotte, R.M.; Cappuzzo, F.; Orlandi, F.; Stroyakovskiy, D.; Nogami, N.; Rodríguez-Abreu, D.; Moro-Sibilot, D.; et al. Atezolizumab plus bevacizumab and chemotherapy in non-small-cell lung cancer (IMpower150): Key subgroup analyses of patients with EGFR mutations or baseline liver metastases in a randomised, open-label phase 3 trial. Lancet Respir. Med. 2019, 7, 387-401. [CrossRef]

49. Socinski, M.A.; Jotte, R.M.; Cappuzzo, F.; Orlandi, F.; Stroyakovskiy, D.; Nogami, N.; Rodríguez-Abreu, D.; Moro-Sibilot, D.; Thomas, C.A.; Barlesi, F.; et al. Atezolizumab for First-Line Treatment of Metastatic Nonsquamous NSCLC. N. Engl. J. Med. 2018, 378, 2288-2301. [CrossRef]

50. Cheng, A.L.; Qin, S.; Ikeda, M.; Galle, P.; Ducreux, M.; Zhu, A.; Kim, T.; Kudo, M.; Breder, V.; Merle, P.; et al. Abstract LBA3 'IMbrave150: Efficacy and safety results from a ph III study evaluating atezolizumab (atezo) + bevacizumab (bev) vs sorafenib (Sor) as first treatment (tx) for patients (pts) with unresectable hepatocellular carcinoma (HCC)'. Ann. Oncol. 2019, 30, ix186-ix187. [CrossRef]

51. Finn, R.S.; Qin, S.; Ikeda, M.; Galle, P.R.; Ducreux, M.; Kim, T.Y.; Kudo, M.; Breder, V.; Merle, P.; Kaseb, A.O.; et al. Atezolizumab plus Bevacizumab in Unresectable Hepatocellular Carcinoma. N. Engl. J. Med. 2020, 382, 1894-1905. [CrossRef] [PubMed]

52. Langer, C.J.; Gadgeel, S.M.; Borghaei, H.; Papadimitrakopoulou, V.A.; Patnaik, A.; Powell, S.F.; Gentzler, R.D.; Martins, R.G.; Stevenson, J.P.; Jalal, S.I.; et al. Carboplatin and pemetrexed with or without pembrolizumab for advanced, non-squamous non-small-cell lung cancer: A randomised, phase 2 cohort of the open-label KEYNOTE-021 study. Lancet Oncol. 2016, 17, 1497-1508. [CrossRef]

53. Rini, B.I.; Powles, T.; Atkins, M.B.; Escudier, B.; McDermott, D.F.; Suarez, C.; Bracarda, S.; Stadler, W.M.; Donskov, F.; Lee, J.L.; et al. Atezolizumab plus bevacizumab versus sunitinib in patients with previously untreated metastatic renal cell carcinoma (IMmotion151): A multicentre, open-label, phase 3, randomised controlled trial. Lancet 2019, 393, 2404-2415. [CrossRef]

54. McDermott, D.F.; Huseni, M.A.; Atkins, M.B.; Motzer, R.J.; Rini, B.I.; Escudier, B.; Fong, L.; Joseph, R.W.; Pal, S.K.; Reeves, J.A.; et al. Clinical activity and molecular correlates of response to atezolizumab alone or in combination with bevacizumab versus sunitinib in renal cell carcinoma. Nat. Med. 2018, 24, 749-757. [CrossRef]

55. Hochster, H.S.; Bendell, J.C.; Cleary, J.M.; Foster, P.; Zhang, W.; He, X.; Hernandez, G.; Iizuka, K.; Eckhardt, S.G. Efficacy and safety of atezolizumab (atezo) and bevacizumab (bev) in a phase Ib study of microsatellite instability (MSI)-high metastatic colorectal cancer (mCRC). J. Clin. Oncol. 2017, 35, 637. [CrossRef]

56. Hodi, F.S.; Lawrence, D.; Lezcano, C.; Wu, X.; Zhou, J.; Sasada, T.; Zeng, W.; Giobbie-Hurder, A.; Atkins, M.B.; Ibrahim, N.; et al. Bevacizumab plus ipilimumab in patients with metastatic melanoma. Cancer Immunol. Res. 2014, 2, 632-642. [CrossRef]

57. Brochez, L.; Chevolet, I.; Kruse, V. The rationale of indoleamine 2, 3-dioxygenase inhibition for cancer therapy. Eur. J. Cancer 2017, 76, 167-182. [CrossRef]

58. Muller, A.J.; Manfredi, M.G.; Zakharia, Y.; Prendergast, G.C. Inhibiting IDO pathways to treat cancer: Lessons from the ECHO-301 trial and beyond. Semin. Immunopathol. 2019, 41, 41-48. [CrossRef]

59. Théate, I.; van Baren, N.; Pilotte, L.; Moulin, P.; Larrieu, P.; Renauld, J.C.; Hervé, C.; Gutierrez-Roelens, I.; Marbaix, E.; Sempoux, C.; et al. Extensive profiling of the expression of the indoleamine 2, 3-dioxygenase 1 protein in normal and tumoral human tissues. Cancer Immunol. Res. 2015, 3, 161-172. [CrossRef]

60. Munn, D.H.; Sharma, M.D.; Baban, B.; Harding, H.P.; Zhang, Y.; Ron, D.; Mellor, A.L. GCN2 kinase in T cells mediates proliferative arrest and anergy induction in response to indoleamine 2,3-dioxygenase. Immunity 2005, 22, 633-642. [CrossRef]

61. Nguyen, N.T.; Kimura, A.; Nakahama, T.; Chinen, I.; Masuda, K.; Nohara, K.; Fujii-Kuriyama, Y.; Kishimoto, T. Aryl hydrocarbon receptor negatively regulates dendritic cell immunogenicity via a kynurenine-dependent mechanism. Proc. Natl. Acad. Sci. USA 2010, 107, 19961-19966. [CrossRef] [PubMed] 
62. Munn, D.H.; Zhou, M.; Attwood, J.T.; Bondarev, I.; Conway, S.J.; Marshall, B.; Brown, C.; Mellor, A.L. Prevention of allogeneic fetal rejection by tryptophan catabolism. Science 1998, 281, 1191-1193. [CrossRef] [PubMed]

63. Mellor, A.L.; Baban, B.; Chandler, P.; Marshall, B.; Jhaver, K.; Hansen, A.; Koni, P.A.; Iwashima, M.; Munn, D.H. Cutting edge: Induced indoleamine 2,3 dioxygenase expression in dendritic cell subsets suppresses $\mathrm{T}$ cell clonal expansion. J. Immunol. 2003, 171, 1652-1655. [CrossRef] [PubMed]

64. Yu, J.; Sun, J.; Wang, S.E.; Li, H.; Cao, S.; Cong, Y.; Liu, J.; Ren, X. Upregulated expression of indoleamine 2, 3-dioxygenase in primary breast cancer correlates with increase of infiltrated regulatory $\mathrm{T}$ cells in situ and lymph node metastasis. Clin. Dev. Immunol. 2011, 2011, 469135. [CrossRef]

65. Brandacher, G.; Perathoner, A.; Ladurner, R.; Schneeberger, S.; Obrist, P.; Winkler, C.; Werner, E.R.; Werner-Felmayer, G.; Weiss, H.G.; Göbel, G.; et al. Prognostic value of indoleamine 2, 3-dioxygenase expression in colorectal cancer: Effect on tumor-infiltrating T cells. Clin. Cancer Res. 2006, 12, 1144-1151. [CrossRef] [PubMed]

66. Ino, K.; Yamamoto, E.; Shibata, K.; Kajiyama, H.; Yoshida, N.; Terauchi, M.; Nawa, A.; Nagasaka, T.; Takikawa, O.; Kikkawa, F. Inverse correlation between tumoral indoleamine 2, 3-dioxygenase expression and tumor-infiltrating lymphocytes in endometrial cancer: Its association with disease progression and survival. Clin. Cancer Res. 2008, 14, 2310-2317. [CrossRef] [PubMed]

67. Chevolet, I.; Speeckaert, R.; Haspeslagh, M.; Neyns, B.; Krüse, V.; Schreuer, M.; Van Gele, M.; Van Geel, N.; Brochez, L. Peritumoral indoleamine 2,3-dioxygenase expression in melanoma: An early marker of resistance to immune control? Br. J. Dermatol. 2014, 171, 987-995. [CrossRef]

68. Holmgaard, R.B.; Zamarin, D.; Munn, D.H.; Wolchok, J.D.; Allison, J.P. Indoleamine 2,3-dioxygenase is a critical resistance mechanism in antitumor T cell immunotherapy targeting CTLA-4. J. Exp. Med. 2013, 210, 1389-1402. [CrossRef]

69. Muller, A.J.; DuHadaway, J.B.; Donover, P.S.; Sutanto-Ward, E.; Prendergast, G.C. Inhibition of indoleamine 2, 3-dioxygenase, an immunoregulatory target of the cancer suppression gene Bin1, potentiates cancer chemotherapy. Nat. Med. 2005, 11, 312-319. [CrossRef]

70. Liu, M.; Wang, X.; Wang, L.; Ma, X.; Gong, Z.; Zhang, S.; Li, Y. Targeting the IDO1 pathway in cancer: From bench to bedside. J. Hematol. Oncol. 2018, 11, 100. [CrossRef]

71. Komiya, T.; Huang, C.H. Updates in the Clinical Development of Epacadostat and Other Indoleamine 2,3-Dioxygenase 1 Inhibitors (IDO1) for Human Cancers. Front. Oncol. 2018, 8, 423. [CrossRef]

72. Jochems, C.; Fantini, M.; Fernando, R.I.; Kwilas, A.R.; Donahue, R.N.; Lepone, L.M.; Grenga, I.; Kim, Y.S.; Brechbiel, M.W.; Gulley, J.L.; et al. The IDO1 selective inhibitor epacadostat enhances dendritic cell immunogenicity and lytic ability of tumor antigen-specific T cells. Oncotarget 2016, 7, 37762-37772. [CrossRef]

73. Beatty, G.L.; O’Dwyer, P.J.; Clark, J.; Shi, J.G.; Bowman, K.J.; Scherle, P.A.; Newton, R.C.; Schaub, R.; Maleski, J.; Leopold, L.; et al. First-in-Human Phase I Study of the Oral Inhibitor of Indoleamine 2,3-Dioxygenase-1 Epacadostat (INCB024360) in Patients with Advanced Solid Malignancies. Clin. Cancer Res. 2017, 23, 3269-3276. [CrossRef]

74. Hamid, O.; Bauer, T.M.; Spira, A.I.; Smith, D.C.; Olszanski, A.J.; Tarhini, A.A.; Lara, P.; Gajewski, T.; Wasser, J.S.; Patel, S.P.; et al. Safety of epacadostat $100 \mathrm{mg}$ bid plus pembrolizumab $200 \mathrm{mg}$ Q3W in advanced solid tumors: Phase 2 data from ECHO-202/KEYNOTE-037. J. Clin. Oncol. 2017, 35, 3012. [CrossRef]

75. Mitchell, T.C.; Hamid, O.; Smith, D.C.; Bauer, T.M.; Wasser, J.S.; Olszanski, A.J.; Luke, J.J.; Balmanoukian, A.S.; Schmidt, E.V.; Zhao, Y.; et al. Epacadostat Plus Pembrolizumab in Patients With Advanced Solid Tumors: Phase I Results From a Multicenter, Open-Label Phase I/II Trial (ECHO-202/KEYNOTE-037). J. Clin. Oncol. 2018, 36, 3223. [CrossRef] [PubMed]

76. Perez, R.P.; Riese, M.J.; Lewis, K.D.; Saleh, M.N.; Daud, A.; Berlin, J.; Lee, J.J.; Mukhopadhyay, S.; Zhou, L.; Serbest, G.; et al. Epacadostat plus nivolumab in patients with advanced solid tumors: Preliminary phase I/II results of ECHO-204. J. Clin. Oncol. 2017, 35, 3003. [CrossRef]

77. Long, G.V.; Dummer, R.; Hamid, O.; Gajewski, T.F.; Caglevic, C.; Dalle, S.; Arance, A.; Carlino, M.S.; Grob, J.J.; Kim, T.M.; et al. Epacadostat plus pembrolizumab versus placebo plus pembrolizumab in patients with unresectable or metastatic melanoma (ECHO-301/KEYNOTE-252): A phase 3, randomised, double-blind study. Lancet Oncol. 2019, 20, 1083-1097. [CrossRef] 
78. Clinicaltrial.gov. Available online: https://clinicaltrials.gov/ct2/results?term=epacadostat\&Search=Apply\& age_v $=\& g n d r=\&$ type $=\& r s l t=($ accessed on 1 May 2020).

79. Jung, K.H.; LoRusso, P.; Burris, H.; Gordon, M.; Bang, Y.J.; Hellmann, M.D.; Cervantes, A.; de Olza, M.O.; Marabelle, A.; Hodi, F.S.; et al. Phase I Study of the Indoleamine 2, 3-Dioxygenase 1 (IDO1) Inhibitor Navoximod (GDC-0919) Administered with PD-L1 Inhibitor (Atezolizumab) in Advanced Solid Tumors. Clin. Cancer Res. 2019, 25, 3220-3228. [CrossRef]

80. Sonpavde, G.; Necchi, A.; Gupta, S.; Steinberg, G.D.; Gschwend, J.E.; Van Der Heijden, M.S.; Garzon, N.; Ibrahim, M.; Raybold, B.; Liaw, D.; et al. ENERGIZE: A Phase III study of neoadjuvant chemotherapy alone or with nivolumab with/without linrodostat mesylate for muscle-invasive bladder cancer. Future Oncol. 2020, 16, 4359-4368. [CrossRef]

81. Günther, J.; Däbritz, J.; Wirthgen, E. Limitations and Off-Target Effects of Tryptophan-Related IDO Inhibitors in Cancer Treatment. Front. Immunol. 2019, 10, 1801. [CrossRef]

82. Mossmann, D.; Park, S.; Hall, M.N. mTOR signalling and cellular metabolism are mutual determinants in cancer. Nat. Rev. Cancer 2018, 18, 744-757. [CrossRef] [PubMed]

83. Vanhaesebroeck, B.; Guillermet-Guibert, J.; Graupera, M.; Bilanges, B. The emerging mechanisms of isoform-specific PI3K signalling. Nat. Rev. Mol. Cell Biol. 2010, 11, 329-341. [CrossRef] [PubMed]

84. O'Donnell, J.S.; Massi, D.; Teng, M.W.L.; Mandala, M. PI3K-AKT-mTOR inhibition in cancer immunotherapy, redux. Semin. Cancer Biol. 2018, 48, 91-103. [CrossRef] [PubMed]

85. Okkenhaug, K. Signaling by the phosphoinositide 3-kinase family in immune cells. Ann. Rev. Immunol. 2013, 31, 675-704. [CrossRef]

86. Peng, W.; Chen, J.Q.; Liu, C.; Malu, S.; Creasy, C.; Tetzlaff, M.T.; Xu, C.; McKenzie, J.A.; Zhang, C.; Liang, X.; et al. Loss of PTEN Promotes Resistance to T Cell-Mediated Immunotherapy. Cancer Discov. 2016, 6, $202-216$. [CrossRef]

87. Borcoman, E.; De La Rochere, P.; Richer, W.; Vacher, S.; Chemlali, W.; Krucker, C.; Sirab, N.; Radvanyi, F.; Allory, Y.; Pignot, G.; et al. Inhibition of PI3K pathway increases immune infiltrate in muscle-invasive bladder cancer. Oncoimmunology 2019, 8, e1581556. [CrossRef]

88. Lastwika, K.J.; Wilson, W.; Li, Q.K.; Norris, J.; Xu, H.; Ghazarian, S.R.; Kitagawa, H.; Kawabata, S.; Taube, J.M.; Yao, S.; et al. Control of PD-L1 Expression by Oncogenic Activation of the AKT-mTOR Pathway in Non-Small Cell Lung Cancer. Cancer Res. 2016, 76, 227-238. [CrossRef]

89. Mittendorf, E.A.; Philips, A.V.; Meric-Bernstam, F.; Qiao, N.; Wu, Y.; Harrington, S.; Su, X.; Wang, Y.; Gonzalez-Angulo, A.M.; Akcakanat, A.; et al. PD-L1 expression in triple-negative breast cancer. Cancer Immunol. Res. 2014, 2, 361-370. [CrossRef]

90. Song, M.; Chen, D.; Lu, B.; Wang, C.; Zhang, J.; Huang, L.; Wang, X.; Timmons, C.L.; Hu, J.; Liu, B.; et al. PTEN loss increases PD-L1 protein expression and affects the correlation between PD-L1 expression and clinical parameters in colorectal cancer. PLoS ONE 2013, 8, e65821. [CrossRef]

91. Ali, K.; Soond, D.R.; Pineiro, R.; Hagemann, T.; Pearce, W.; Lim, E.L.; Bouabe, H.; Scudamore, C.L.; Hancox, T.; Maecker, H.; et al. Inactivation of PI(3)K p1108 breaks regulatory T-cell-mediated immune tolerance to cancer. Nature 2014, 510, 407-411. [CrossRef]

92. Patton, D.T.; Garden, O.A.; Pearce, W.P.; Clough, L.E.; Monk, C.R.; Leung, E.; Rowan, W.C.; Sancho, S.; Walker, L.S.; Vanhaesebroeck, B.; et al. Cutting edge: The phosphoinositide 3-kinase p110 delta is critical for the function of CD4+CD25+Foxp3+ regulatory T cells. J. Immunol. 2006, 177, 6598-6602. [CrossRef] [PubMed]

93. Abu-Eid, R.; Samara, R.N.; Ozbun, L.; Abdalla, M.Y.; Berzofsky, J.A.; Friedman, K.M.; Mkrtichyan, M.; Khleif, S.N. Selective inhibition of regulatory T cells by targeting the PI3K-Akt pathway. Cancer Immunol. Res. 2014, 2, 1080-1089. [CrossRef] [PubMed]

94. Kim, E.H.; Suresh, M. Role of PI3K/Akt signaling in memory CD8 T cell differentiation. Front. Immunol. 2013, 4, 20. [CrossRef] [PubMed]

95. Kaneda, M.M.; Messer, K.S.; Ralainirina, N.; Li, H.; Leem, C.J.; Gorjestani, S.; Woo, G.; Nguyen, A.V.; Figueiredo, C.C.; Foubert, P.; et al. PI3K $\gamma$ is a molecular switch that controls immune suppression. Nature 2016, 539, 437-442. [CrossRef] [PubMed] 
96. Schmid, P.; Loirat, D.; Savas, P.; Espinosa, E.; Boni, V.; Italiano, A.; White, S.; Singel, S.M.; Withana, N.; Mani, A.; et al. Abstract CT049: Phase Ib study evaluating a triplet combination of ipatasertib (IPAT), atezolizumab (atezo), and paclitaxel (PAC) or nab-PAC as first-line (1L) therapy for locally advanced/metastatic triple-negative breast cancer (TNBC). Cancer Res. 2019, 79, CT049. [CrossRef]

97. Noy, R.; Pollard, J.W. Tumor-associated macrophages: From mechanisms to therapy. Immunity 2014, 41, 49-61. [CrossRef]

98. Baay, M.; Brouwer, A.; Pauwels, P.; Peeters, M.; Lardon, F. Tumor cells and tumor-associated macrophages: Secreted proteins as potential targets for therapy. Clin. Dev. Immunol. 2011, 2011, 565187. [CrossRef]

99. Fujimura, T.; Kambayashi, Y.; Fujisawa, Y.; Hidaka, T.; Aiba, S. Tumor-Associated Macrophages: Therapeutic Targets for Skin Cancer. Front. Oncol. 2018, 8, 3. [CrossRef]

100. Majety, M.; Runza, V.; Lehmann, C.; Hoves, S.; Ries, C.H. A drug development perspective on targeting tumor-associated myeloid cells. FEBS J. 2018, 285, 763-776. [CrossRef]

101. Ries, C.H.; Cannarile, M.A.; Hoves, S.; Benz, J.; Wartha, K.; Runza, V.; Rey-Giraud, F.; Pradel, L.P.; Feuerhake, F.; Klaman, I.; et al. Targeting tumor-associated macrophages with anti-CSF-1R antibody reveals a strategy for cancer therapy. Cancer Cell 2014, 25, 846-859. [CrossRef]

102. Cannarile, M.A.; Weisser, M.; Jacob, W.; Jegg, A.M.; Ries, C.H.; Rüttinger, D. Colony-stimulating factor 1 receptor (CSF1R) inhibitors in cancer therapy. J. Immunother. Cancer 2017, 5, 53. [CrossRef] [PubMed]

103. Kowal, J.; Kornete, M.; Joyce, J.A. Re-education of macrophages as a therapeutic strategy in cancer. Immunotherapy 2019, 11, 677-689. [CrossRef] [PubMed]

104. Advani, R.; Flinn, I.; Popplewell, L.; Forero, A.; Bartlett, N.L.; Ghosh, N.; Kline, J.; Roschewski, M.; LaCasce, A.; Collins, G.P.; et al. CD47 Blockade by Hu5F9-G4 and Rituximab in Non-Hodgkin's Lymphoma. N. Engl. J. Med. 2018, 379, 1711-1721. [CrossRef] [PubMed]

105. Advani, R.; Volkmer, J.P.; Chao, M.P. CD47 Blockade and Rituximab in Non-Hodgkin's Lymphoma. N. Engl. J. Med. 2019, 380, 497-498. [CrossRef]

106. Chao, M.P.; Takimoto, C.H.; Feng, D.D.; McKenna, K.; Gip, P.; Liu, J.; Volkmer, J.P.; Weissman, I.L.; Majeti, R. Therapeutic Targeting of the Macrophage Immune Checkpoint CD47 in Myeloid Malignancies. Front. Oncol. 2019, 9, 1380. [CrossRef]

107. Donnelly, D.; Bajaj, S.; Yu, J.; Hsu, M.; Balar, A.; Pavlick, A.; Weber, J.; Osman, I.; Zhong, J. The complex relationship between body mass index and response to immune checkpoint inhibition in metastatic melanoma patients. J. Immunother. Cancer 2019, 7, 222. [CrossRef]

108. Gopalakrishnan, V.; Spencer, C.N.; Nezi, L.; Reuben, A.; Andrews, M.C.; Karpinets, T.V.; Prieto, P.A.; Vicente, D.; Hoffman, K.; Wei, S.C.; et al. Gut microbiome modulates response to anti-PD-1 immunotherapy in melanoma patients. Science 2018, 359, 97-103. [CrossRef]

109. Sivan, A.; Corrales, L.; Hubert, N.; Williams, J.B.; Aquino-Michaels, K.; Earley, Z.M.; Benyamin, F.W.; Lei, Y.M.; Jabri, B.; Alegre, M.L.; et al. Commensal Bifidobacterium promotes antitumor immunity and facilitates anti-PD-L1 efficacy. Science 2015, 350, 1084-1089. [CrossRef]

110. WCRF. Available online: www.wcrf.org (accessed on 1 May 2020).

111. Fleming, G.F.; Emens, L.A.; Eder, J.P.; Hamilton, E.P.; Liu, J.F.; Liu, B.; Molinero, L.; Fasso, M.; O’Hear, C.; Braiteh, F.S. Clinical activity, sefety and biomarker results from a phase Ia study of atezolizumab (atezo) in advanced/recurrent endometrial cancer(rEC). J. Clin. Oncol. 2017, 35, 5582. [CrossRef]

112. Schlesinger, S.; Siegert, S.; Koch, M.; Walter, J.; Heits, N.; Hinz, S.; Jacobs, G.; Hampe, J.; Schafmayer, C.; Nöthlings, U. Postdiagnosis body mass index and risk of mortality in colorectal cancer survivors: A prospective study and meta-analysis. Cancer Causes Control 2014, 25, 1407-1418. [CrossRef]

113. Hakimi, A.A.; Furberg, H.; Zabor, E.C.; Jacobsen, A.; Schultz, N.; Ciriello, G.; Mikklineni, N.; Fiegoli, B.; Kim, P.H.; Voss, M.H.; et al. An epidemiologic and genomic investigation into the obesity paradox in renal cell carcinoma. J. Natl. Cancer Inst. 2013, 105, 1862-1870. [CrossRef] [PubMed]

114. Amptoulach, S.; Gross, G.; Kalaitzakis, E. Differential impact of obesity and diabetes mellitus on survival after liver resection for colorectal cancer metastases. J. Surg. Res. 2015, 199, 378-385. [CrossRef] [PubMed]

115. Brunner, A.M.; Sadrzadeh, H.; Feng, Y.; Drapkin, B.J.; Ballen, K.K.; Attar, E.C.; Amrein, P.C.; McAfee, S.L.; Chen, Y.B.; Neuberg, D.S.; et al. Association between baseline body mass index and overall survival among patients over age 60 with acute myeloid leukemia. Am. J. Hematol. 2013, 88, 642-646. [CrossRef] 
116. Tsang, N.M.; Pai, P.C.; Chuang, C.C.; Chuang, W.C.; Tseng, C.K.; Chang, K.P.; Yen, T.C.; Lin, J.D.; Chang, J.T. Overweight and obesity predict better overall survival rates in cancer patients with distant metastases. Cancer Med. 2016, 5, 665-675. [CrossRef]

117. Parker, A.S.; Lohse, C.M.; Cheville, J.C.; Thiel, D.D.; Leibovich, B.C.; Blute, M.L. Greater body mass index is associated with better pathologic features and improved outcome among patients treated surgically for clear cell renal cell carcinoma. Urology 2006, 68, 741-746. [CrossRef] [PubMed]

118. Lennon, H.; Sperrin, M.; Badrick, E.; Renehan, A.G. The Obesity Paradox in Cancer: A Review. Curr. Oncol. Rep. 2016, 18, 56. [CrossRef]

119. Navarro, W.H.; Loberiza, F.R.; Bajorunaite, R.; van Besien, K.; Vose, J.M.; Lazarus, H.M.; Rizzo, J.D. Effect of body mass index on mortality of patients with lymphoma undergoing autologous hematopoietic cell transplantation. Biol. Blood Marrow Transpl. 2006, 12, 541-551. [CrossRef]

120. Giulia, G.; Paola, C.; Roberto, F.; Arsela, P.; Claudia, P.; Diego, S.; Nicoletta, Z.; Alessandro, D.T.; Filippo, P.; Giovanni, R.; et al. Impact of cholesterolemia and body mass index on outcome of metastatic non small cell lung cancer treated with immunotherapy. J. Clin. Oncol. 2019, 37. [CrossRef]

121. Rassy, E.E.; Ghosn, M.; Rassy, N.A.; Assi, T.; Robert, C. Do immune checkpoint inhibitors perform identically in patients with weight extremes? Immunotherapy 2018, 10, 733-736. [CrossRef]

122. Dirks, N.L.; Meibohm, B. Population pharmacokinetics of therapeutic monoclonal antibodies. Clin. Pharm. 2010, 49, 633-659. [CrossRef]

123. Wu, S.; Liu, J.; Wang, X.; Li, M.; Gan, Y.; Tang, Y. Association of obesity and overweight with overall survival in colorectal cancer patients: A meta-analysis of 29 studies. Cancer Causes Control 2014, 25, 1489-1502. [CrossRef] [PubMed]

124. Navarro, W.H.; Agovi, M.A.; Logan, B.R.; Ballen, K.; Bolwell, B.J.; Frangoul, H.; Gupta, V.; Hahn, T.; Ho, V.T.; Juckett, M.; et al. Obesity does not preclude safe and effective myeloablative hematopoietic cell transplantation (HCT) for acute myelogenous leukemia (AML) in adults. Biol. Blood Marrow Transpl. 2010, 16, 1442-1450. [CrossRef] [PubMed]

125. Gonzalez, M.C.; Pastore, C.A.; Orlandi, S.P.; Heymsfield, S.B. Obesity paradox in cancer: New insights provided by body composition. Am. J. Clin. Nutr. 2014, 99, 999-1005. [CrossRef] [PubMed]

126. Wang, S.; Cowley, L.A.; Liu, X.S. Sex Differences in Cancer Immunotherapy Efficacy, Biomarkers, and Therapeutic Strategy. Molecules 2019, 24, 3214. [CrossRef]

127. Wagner, A.D.; Oertelt-Prigione, S.; Adjei, A.; Buclin, T.; Cristina, V.; Csajka, C.; Coukos, G.; Dafni, U.; Dotto, G.P.; Ducreux, M.; et al. Gender medicine and oncology: Report and consensus of an ESMO workshop. Ann. Oncol. 2019, 30, 1914-1924. [CrossRef] [PubMed]

128. Botticelli, A.; Onesti, C.E.; Zizzari, I.; Cerbelli, B.; Sciattella, P.; Occhipinti, M.; Roberto, M.; Di Pietro, F.; Bonifacino, A.; Ghidini, M.; et al. The sexist behaviour of immune checkpoint inhibitors in cancer therapy? Oncotarget 2017, 8, 99336-99346. [CrossRef] [PubMed]

129. Wallis, C.J.D.; Butaney, M.; Satkunasivam, R.; Freedland, S.J.; Patel, S.P.; Hamid, O.; Pal, S.K.; Klaassen, Z. Association of Patient Sex With Efficacy of Immune Checkpoint Inhibitors and Overall Survival in Advanced Cancers: A Systematic Review and Meta-analysis. JAMA Oncol. 2019, 5, 529-536. [CrossRef]

130. Wang, C.; Qiao, W.; Jiang, Y.; Zhu, M.; Shao, J.; Ren, P.; Liu, D.; Li, W. Effect of sex on the efficacy of patients receiving immune checkpoint inhibitors in advanced non-small cell lung cancer. Cancer Med. 2019, 8, 4023-4031. [CrossRef]

131. Grassadonia, A.; Sperduti, I.; Vici, P.; Iezzi, L.; Brocco, D.; Gamucci, T.; Pizzuti, L.; Maugeri-Saccà, M.; Marchetti, P.; Cognetti, G.; et al. Effect of Gender on the Outcome of Patients Receiving Immune Checkpoint Inhibitors for Advanced Cancer: A Systematic Review and Meta-Analysis of Phase III Randomized Clinical Trials. J. Clin. Med. 2018, 7, 542. [CrossRef]

132. Wu, Y.; Ju, Q.; Jia, K.; Yu, J.; Shi, H.; Wu, H.; Jiang, M. Correlation between sex and efficacy of immune checkpoint inhibitors (PD-1 and CTLA-4 inhibitors). Int. J. Cancer 2018, 143, 45-51. [CrossRef]

133. Klein, S.L.; Flanagan, K.L. Sex differences in immune responses. Nat. Rev. Immunol. 2016, 16, 626-638. [CrossRef]

134. Abdel-Rahman, O. Does a patient's sex predict the efficacy of cancer immunotherapy? Lancet Oncol. 2018, 19, 716-717. [CrossRef]

135. Ye, Y.; Jing, Y.; Li, L.; Mills, G.B.; Diao, L.; Liu, H.; Han, L. Sex-associated molecular differences for cancer immunotherapy. Nat. Commun. 2020, 11, 1779. [CrossRef] [PubMed] 
136. Ley, R.E.; Peterson, D.A.; Gordon, J.I. Ecological and evolutionary forces shaping microbial diversity in the human intestine. Cell 2006, 124, 837-848. [CrossRef] [PubMed]

137. Hooper, L.V.; Littman, D.R.; Macpherson, A.J. Interactions between the microbiota and the immune system. Science 2012, 336, 1268-1273. [CrossRef] [PubMed]

138. Zitvogel, L.; Ayyoub, M.; Routy, B.; Kroemer, G. Microbiome and Anticancer Immunosurveillance. Cell 2016, 165, 276-287. [CrossRef]

139. Vétizou, M.; Pitt, J.M.; Daillère, R.; Lepage, P.; Waldschmitt, N.; Flament, C.; Rusakiewicz, S.; Routy, B.; Roberti, M.P.; Duong, C.P.; et al. Anticancer immunotherapy by CTLA-4 blockade relies on the gut microbiota. Science 2015, 350, 1079-1084. [CrossRef]

140. Routy, B.; Le Chatelier, E.; Derosa, L.; Duong, C.P.M.; Alou, M.T.; Daillère, R.; Fluckiger, A.; Messaoudene, M.; Rauber, C.; Roberti, M.P.; et al. Gut microbiome influences efficacy of PD-1-based immunotherapy against epithelial tumors. Science 2018, 359, 91-97. [CrossRef]

141. Matson, V.; Fessler, J.; Bao, R.; Chongsuwat, T.; Zha, Y.; Alegre, M.L.; Luke, J.J.; Gajewski, T.F. The commensal microbiome is associated with anti-PD-1 efficacy in metastatic melanoma patients. Science 2018, 359, 104-108. [CrossRef]

142. Frankel, A.E.; Coughlin, L.A.; Kim, J.; Froehlich, T.W.; Xie, Y.; Frenkel, E.P.; Koh, A.Y. Metagenomic Shotgun Sequencing and Unbiased Metabolomic Profiling Identify Specific Human Gut Microbiota and Metabolites Associated with Immune Checkpoint Therapy Efficacy in Melanoma Patients. Neoplasia 2017, 19, 848-855. [CrossRef]

143. Ahmed, J.; Kumar, A.; Parikh, K.; Anwar, A.; Knoll, B.M.; Puccio, C.; Chun, H.; Fanucchi, M.; Lim, S.H. Use of broad-spectrum antibiotics impacts outcome in patients treated with immune checkpoint inhibitors. Oncoimmunology 2018, 7, e1507670. [CrossRef] [PubMed]

144. Derosa, L.; Hellmann, M.D.; Spaziano, M.; Halpenny, D.; Fidelle, M.; Rizvi, H.; Long, N.; Plodkowski, A.J.; Arbour, K.C.; Chaft, J.E.; et al. Negative association of antibiotics on clinical activity of immune checkpoint inhibitors in patients with advanced renal cell and non-small-cell lung cancer. Ann. Oncol. 2018, 29, 1437-1444. [CrossRef] [PubMed]

145. Kaderbhai, C.; Richard, C.; Fumet, J.D.; Aarnink, A.; Foucher, P.; Coudert, B.; Favier, L.; Lagrange, A.; Limagne, E.; Boidot, R.; et al. Antibiotic Use Does Not Appear to Influence Response to Nivolumab. Anticancer Res. 2017, 37, 3195-3200. [CrossRef] [PubMed]

146. Chalabi, M.; Cardona, A.; Nagarkar, D.R.; Dhawahir Scala, A.; Gandara, D.R.; Rittmeyer, A.; Albert, M.L.; Powles, T.; Kok, M.; Herrera, F.G.; et al. Efficacy of chemotherapy and atezolizumab in patients with non-small-cell lung cancer receiving antibiotics and proton pump inhibitors: Pooled post hoc analyses of the OAK and POPLAR trials. Ann. Oncol. 2020, 31, 525-531. [CrossRef] [PubMed]

147. Jackson, M.A.; Goodrich, J.K.; Maxan, M.E.; Freedberg, D.E.; Abrams, J.A.; Poole, A.C.; Sutter, J.L.; Welter, D.; Ley, R.E.; Bell, J.T.; et al. Proton pump inhibitors alter the composition of the gut microbiota. Gut 2016, 65, 749-756. [CrossRef]

148. Dubin, K.; Callahan, M.K.; Ren, B.; Khanin, R.; Viale, A.; Ling, L.; No, D.; Gobourne, A.; Littmann, E.; Huttenhower, C.; et al. Intestinal microbiome analyses identify melanoma patients at risk for checkpointblockade-induced colitis. Nat. Commun. 2016, 7, 10391. [CrossRef]

149. Chaput, N.; Lepage, P.; Coutzac, C.; Soularue, E.; Le Roux, K.; Monot, C.; Boselli, L.; Routier, E.; Cassard, L.; Collins, M.; et al. Baseline gut microbiota predicts clinical response and colitis in metastatic melanoma patients treated with ipilimumab. Ann. Oncol. 2017, 28, 1368-1379. [CrossRef]

150. Wang, Y.; Wiesnoski, D.H.; Helmink, B.A.; Gopalakrishnan, V.; Choi, K.; DuPont, H.L.; Jiang, Z.D.; Abu-Sbeih, H.; Sanchez, C.A.; Chang, C.C.; et al. Fecal microbiota transplantation for refractory immune checkpoint inhibitor-associated colitis. Nat. Med. 2018, 24, 1804-1808. [CrossRef]

151. Buck, M.D.; Sowell, R.T.; Kaech, S.M.; Pearce, E.L. Metabolic Instruction of Immunity. Cell 2017, 169, 570-586. [CrossRef]

152. Pitt, J.M.; Vétizou, M.; Daillère, R.; Roberti, M.P.; Yamazaki, T.; Routy, B.; Lepage, P.; Boneca, I.G.; Chamaillard, M.; Kroemer, G.; et al. Resistance Mechanisms to Immune-Checkpoint Blockade in Cancer: Tumor-Intrinsic and -Extrinsic Factors. Immunity 2016, 44, 1255-1269. [CrossRef]

153. Gibney, G.T.; Weiner, L.M.; Atkins, M.B. Predictive biomarkers for checkpoint inhibitor-based immunotherapy. Lancet Oncol. 2016, 17, e542-e551. [CrossRef] 
154. Havel, J.J.; Chowell, D.; Chan, T.A. The evolving landscape of biomarkers for checkpoint inhibitor immunotherapy. Nat. Rev. Cancer 2019, 19, 133-150. [CrossRef] [PubMed]

155. Zaretsky, J.M.; Garcia-Diaz, A.; Shin, D.S.; Escuin-Ordinas, H.; Hugo, W.; Hu-Lieskovan, S.; Torrejon, D.Y.; Abril-Rodriguez, G.; Sandoval, S.; Barthly, L.; et al. Mutations Associated with Acquired Resistance to PD-1 Blockade in Melanoma. N. Engl. J. Med. 2016, 375, 819-829. [CrossRef] [PubMed]

156. Skoulidis, F.; Goldberg, M.E.; Greenawalt, D.M.; Hellmann, M.D.; Awad, M.M.; Gainor, J.F.; Schrock, A.B.; Hartmaier, R.J.; Trabucco, S.E.; Gay, L.; et al. STK11/LKB1 mutations and PD-1 inhibitor resistance in KRAS-mutant lung adenocarcinoma. Cancer Discov. 2018, 8, 822-835. [CrossRef]

157. Mikhaylova, I.N.; Shubina, I.Z.; Chkadua, G.Z.; Petenko, N.N.; Morozova, L.F.; Burova, O.S.; Beabelashvili, R.S.; Parsunkova, K.A.; Balatskaya, N.V.; Chebanov, D.K.; et al. Immunological monitoring for prediction of clinical response to antitumor vaccine therapy. Oncotarget 2018, 9, 24381-24390. [CrossRef]

158. Chowell, D.; Morris, L.G.T.; Grigg, C.M.; Weber, J.K.; Samstein, R.M.; Makarov, V.; Kuo, F.; Kendall, S.M.; Requena, D.; Riaz, N.; et al. Patient HLA class I genotype influences cancer response to checkpoint blockade immunotherapy. Science 2018, 359, 582-587. [CrossRef]

159. Chowell, D.; Krishna, C.; Pierini, F.; Makarov, V.; Rizvi, N.A.; Kuo, F.; Morris, L.G.T.; Riaz, N.; Lenz, T.L.; Chan, T.A. Evolutionary divergence of HLA class I genotype impacts efficacy of cancer immunotherapy. Nat. Med. 2019, 25, 1715-1720. [CrossRef]

160. Zhu, A.X.; Guan, Y.; Abbas, A.R.; Koeppen, H.; Lu, S.; Hsu, C.-H.; Lee, K.-H.; Lee, M.S.; He, A.R.; Mahipal, A.; et al. CT044-Genomic correlates of clinical benefits from atezolizumab combined with bevacizumab vs. atezolizumab alone in patients with advanced hepatocellular carcinoma (HCC). In Proceedings of the AACR Annual Meeting I, 27-28 April 2020.

(C) 2020 by the authors. Licensee MDPI, Basel, Switzerland. This article is an open access article distributed under the terms and conditions of the Creative Commons Attribution (CC BY) license (http://creativecommons.org/licenses/by/4.0/). 